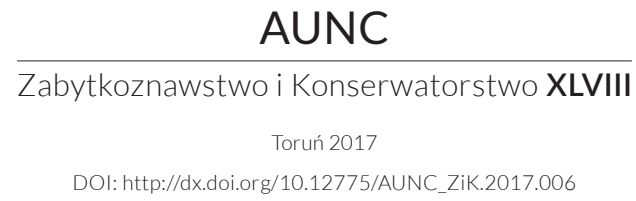

\title{
The organisation of liturgical space and its furnishing at the Franciscan Friars' in late Middle Ages illustrated by an example of the Blessed Virgin Mary's church in Toruń"
}

\author{
MONIKA JAKUBEK-RACZKOWSKA \\ Zakład Historii Sztuki Średniowiecznej i Nowożytnej, \\ Wydział Sztuk Pięknych, UMK w Toruniu \\ e-mail:mracz@umk.pl
}

JULIUSZ RACZKOWSKI

Pracownia Architektury Wnętrz, Wydział Sztuk Pięknych, UMK w Toruniu e-mail: jracz@umk.pl

Keywords: The Franciscans, Gothic, Toruń, brick-built architecture, sacred space, liturgy, lay piety, wall paintings, panel painting, sculpture

Słowa kluczowe: franciszkanie, gotyk, Toruń, architektura ceglana, przestrzeń liturgiczna, pobożność świeckich, malowidła ścienne, malarstwo tablicowe, rzeźba gotycka

The paper is based on studies carried out within a framework of a research project financed by the Ministry of Science and Higher Education, Księga klasztorów ziemi chełmińskiej / The Book of Monasteries of Chełmno Land" (No 747 / NH), realised at the NCU in the years 2012-14, headed by dr hab. Piotr Oliński. The basic matters have been presented at the scientific conference: „Sztuka w kręgu krakowskich franciszkanów i klarysek / Art of the circle of Krakow Franciscan Friars and Order of Poor Clares" (organised by the Institute of the History of Art, Jagiellonian University and the Convent of Franciscan Friars), Kraków 2015 (paper: Organizacja franciszkańskiej przestrzeni 'ecclesiae exterioris' $w$ średniowieczu na przykładzie kościoła NMP w Toruniu). 


\begin{abstract}
At the turn of $14^{\text {th }}$ and in early $15^{\text {th }}$ century the sacred space of the Franciscan St Mary's church in Torun was fully developed and adjusted to the mission and ministry of the Order of Friars Minor, equipped with altars, most important furniture and numerous paintings used in pastoral ministry and in encouraging lay piety. It was completed in the late $15^{\text {th }}$ cent., especially with woodwork (stalls, balustrades, crucifix). Décor and furnishing of ecclesiae fratrum (main altar, murals, choir stalls, as well as rood screen and its altars) are from today's perspective much less palpable. Ecclesia laicorum is in that respect much better preserved (wall paintings, sculptures, baptismal font) or known against written sources (organ, cancel, grave plates) in spite of structural alterations and transformations resulting from denominational and functional changes. The analysed artefacts - though not so numerous, as the material sources significantly complement a skimpy archival base related with functioning of one of the most significant Prussian mendicant convents in Middle Ages.
\end{abstract}

\begin{abstract}
Abstrakt
Organizacja franciszkańskiej przestrzeni liturgicznej i jej wyposażenie w późnym średniowieczu na przykładzie kościoła NMP w Toruniu

Na przełomie XIV i XV wieku przestrzeń liturgiczna kościoła franciszkańskiego pw. NMP w Toruniu była w pełni ukształtowana i przystosowana do misji i posługi zakonu braci mniejszych, wyposażona w ołtarze, najważniejsze elementy wyposażenia oraz liczne malowidła ścienne, wykorzystywane w posłudze duszpasterskiej i pobudzaniu religijnych uczuć u wiernych. Przestrzeń ta została dopełniona w końcu XV wieku za sprawą nowych elementów - stalli, balustrad, krucyfiksu. Wystrój i wyposażenie ecclesiae fratrum (ołtarz główny, dekoracje malarskie, lektorium) jest z dzisiejszej perspektywy uchwytny słabo. Znacznie więcej wiadomo o przestrzeni ecclesaie laicorum, której wystrój zachował się w większym stopniu (malowidła ścienne, rzeźby, chrzcielnica) lub jest uchwytny przez źródła pisane (organy, ambona, płyty nagrobne), także w zakresie zmian strukturalnych i transformacji związanych ze zmianami konfesyjnymi i przemianami funkcji wnętrza. Analizowane w tekście zabytki, choć nie tak liczne, jako źródła materialne są istotnym uzupełnieniem skąpej bazy archiwalnej, dotyczącej funkcjonowania jednego z najważniejszych pruskich konwentów mendykanckich w średniowieczu.
\end{abstract}

The former Franciscan church in Torun belongs among the most significant examples of Prussian brick-built architecture in Middle Ages (the first high hall in the Monastic State of the Teutonic Order). It is also one of the most monumental architectural realisations undertaken by Franciscan Friars in Northern part of Europe. It presents an inalienable value for universal studies on the mendicant architecture, or more broadly - on the architecture of 
the so called Backsteingotik (as a phenomenon typical for the Southern Baltic Coasts). In terms of the mendicant heritage on the territory of the former Monastic State of Teutonic Knights, the Blessed Virgin Mary's church is one of its most significant examples: as the only one the architecture of which is preserved almost unaltered with a good part of its former décor and some remnants of the original furnishing.

That was a lucky chance, since after secularisation of the convent the church had been in Protestant hands for almost 200 years, then was reorganised by the Bernardine Fathers, and after dissolution of their order (in 1817) has served as a parish church (since 1830). In spite of denominational and functional changes, a large portion of its Franciscan legacy survived till our times. Conventual buildings did not survive, but the church itself, as a Franciscan monument is regarded as an important and unique example, also in the European context and has quite a number of studies and attempted interpretations ${ }^{1}$, including two separate analyses of liturgical space in terms of a monastic rule, architecture and ideological contents of décor² ${ }^{2}$. The present

1 Among the most significant studies on the architecture one should mention (listed chronologically): Zbigniew Nawrocki, „Pofranciszkański kościół NMP w Toruniu. Próba rekonstrukcji faz budowy", Acta Universitatis Nicolai Copernici, Zabytkoznawstwo i Konserwatorstwo 2 (1966), 47-80; Teresa Mroczko, „Programy architektoniczne zakonów żebrzących na ziemi chełmińskiej w XIII i XIV wieku”, in Sztuka i ideologia XIV wieku w Polsce, Materiały sympozjum Komitetu Nauk o Sztuce PAN Warszawa, 29 i 30 listopada 1973, ed. Piotr Skubiszewski (Warszawa: SHS, 1975), 317-347; Teresa Mroczko, Architektura gotycka na ziemi chełmińskiej (Warszawa: PWN, 1980), 36-42, 130-143, 293-308; Zbigniew Nawrocki, „Kościół Mariacki w Toruniu - budowa i przebudowy w świetle odkryć w ostatnim ćwierćwieczu”, in Dzieje i skarby kościoła Mariackiego w Toruniu, Materiały z konferencji przygotowanej przez toruński oddział SHS oraz IZiK UMK, Toruń 14-16 kwietnia 2005, ed. Katarzyna Kluczwajd (Toruń: SHS, 2005), 19-53; Liliana Krantz-Domasłowska, „Hala hali nierówna i nie tylko. Próba wpisania kościoła Mariackiego w krajobraz architektoniczny średniowiecznego Torunia”, in Dzieje i skarby kościoła Mariackiego, 87-109; Zbigniew Nawrocki, Pofranciszkański kościót p.w. Wniebowzięcia Najświętszej Marii Panny w Toruniu (Toruń: Parafia NMP, 2006); Monika Jakubek-Raczkowska and Juliusz Raczkowski, „Mendykancki dialog z wiernymi w sztuce wielkich miast państwa zakonnego w Prusach na przykładzie klasztorów ziemi chełmińskiej w XIV i XV wieku”, in Katedra, ratusz, dwór. Wielkie miasta a władza świecka i kościelna $w$ kulturze średniowiecznej Europy, Materiały XXXIII Seminarium Mediewistycznego im. Alicji Karłowskiej-Kamzowej, 29 listopada-1 grudnia 2012 w Poznaniu, ed. Jacek Kowalski, and Tomasz Ratajczak (Poznań: PTPN, 2014), 371-399.

2 Anna Błażejewska, „Czternastowieczny wystrój kościoła Mariackiego w Toruniu: duchowość franciszkańska a pobożność miejska”, in Dzieje i skarby kościoła Mariackiego, 55-85; Liliana Krantz-Domasłowska, „Przestrzeń liturgiczna czternastowiecznego kościoła Franciszkanów w Toruniu", in Album Amicorum. Między Wilnem a Toruniem. Księga pamiątkowa dedykowana prof. Józefowi Poklewskiemu, ed. Piotr Birecki et al. (Toruń: Wydawnictwo Naukowe UMK, 2008), 153-168. 
study is concentrated on the function of the interior and its furnishing in context of the mission and ministry of the order. It focuses not only on the spatial organisation of the church interior till the late $14^{\text {th }}$ century, but also on transformations made at the twilight of Middle Ages.

A monumental, monolithic structure of the temple that assumed its final shape at the end of $14^{\text {th }}$ century dominated the panorama of the then city development of Torun and since the very beginning made an important centre of town's sacred geography (fig. 1). Initially, the convent was to minister to the suburbs inhabited by the rabble and was located extra muros. After spatial reorganisation of the town in mid- $13^{\text {th }}$ century it found itself within the town walls, close to the newly delineated Old Town Market ${ }^{3}$. The convent's ministry had still been addressed mostly to the rabble - which is confirmed by the fact, that it had been associated with such organisations as the guild of pursemakers and glovers ${ }^{4}$ or the fraternity of the Vistula fishermen ${ }^{5}$. Rich merchants of the Old Town naturally tended to associate rather with the parish church of St Johns'.

However, the hope of the virtue of the poor Brethren prayers made the convent church popularity gradually grow also among the patriciate, in $14^{\text {th }}$ century - among the richest Torun families such as von Rockendorf, von Allen, Wale, Werle and others ${ }^{6}$. And thus although existing outside the parish structure it provided them support, made an alternative and in some aspects (not only the pastoral ones) - a competition: gradually it assumed a role of the burghers' memoria. On the other hand one should remember, that it continued to fulfil the task of a convent church. Thus the space of this edifice should be regarded as a multi-functional and multifocal one; its form was influenced by a number of factors, including the intellectual condition and religious awareness of the interior users and of the recipients of the exercised ministry.

In accordance with common rules the basic functional distribution of the space concerned isolation of the conventual section (ecclesia interior, fratrum)

3 See Krantz-Domasłowska, „Hala hali nierówna”, 88-89.

4 Piotr Oliński, „Rola średniowiecznych bractw religijnych w życiu miejskim na przykładzie toruńskiego bractwa kaletników, torebkarzy i rękawiczników”, in Studia nad dziejami miast i mieszczaństwa w średniowieczu, vol. 1, collective editor (Toruń: Wydawnictwo Naukowe UMK, 1996), 77-91; Piotr Oliński, Fundacje mieszczańskie w miastach pruskich w okresie średniowiecza i na progu czasów nowożytnych (Chełmno, Toruń, Elblag, Gdańsk, Królewiec, Braniewo) (Toruń: Wydawnictwo Naukowe UMK, 2008), 512.

5 Oliński, Fundacje mieszczańskie, 513-514.

6 Oliński, Fundacje mieszczańskie, 510-512. 
located at Torun Franciscan Friars' in an architectonic chancel (fig. 2: A), from the section available to the faithful (ecclesia exterior, laicorum; fig. 2: D), that took up the whole main body of the church. In that way the two foundations of the mendicant conventual obligation - the communal office and the ministry - were clearly divided. Both sections of the church underwent significant changes within the $14^{\text {th }}$ century ${ }^{7}$ - the two-naved body of the church has been extended on the south side ${ }^{8}$ and transformed into a threenaved one with a gallery along the north side. At the turn of $14^{\text {th }}$ century it has been extended towards the west by two spans and the vaulting's height has been considerably raised. Also the chancel - earlier narrow and polygonally closed has been widened, extended and it's height has been increased.

It can bee assumed, that the construction works were continuously run till the beginning of the $15^{\text {th }}$ century, and even later the fabrica ecclesiae could make necessary alterations and repairs. Exact phases of extending and altering the structure, once defined by Zbigniew Nawrocki as five successive „churches” (construction phases) in that location ${ }^{9}$, more and more urgently need verification by comprehensive building archaeology and source query. However one can assume, that ca. the year 1400 the church gained a fully-developed form that it has today, final functional distribution and the most significant elements of décor and furnishing (the majority of preserved material testimonies from that church date from mid- $14^{\text {th }}$ to early $15^{\text {th }}$ centuries).

An autonomous space of ecclesiae fratrum at Torun Franciscan Friars' assumed a characteristic form of „a long choir” (fig. 2: A). In the final stage of transformations it gained a form of a four-spanned hall straight-ended

On the church architecture see among others: Mroczko, Architektura gotycka, 130-135, 296-307, 308-312; Teresa Mroczko and Andrzej Włodarek, „Kościół pw. Panny Marii, franciszkanów”, in Architektura gotycka w Polsce, ed. Teresa Mroczko, Marian Arszyński („Dzieje sztuki polskiej” Vol. 2), vol. 2, Katalog zabytków, ed. Andrzej Włodarek (Warszawa: PWN, 1995), 243; Nawrocki, „Pofranciszkański kościół NMP”, 47-80; Nawrocki, „Kościół Mariacki”, 19-53; Nawrocki, Pofranciszkański kościół, 4-27, 243; Jerzy Domasłowski, Jarosław Jarzewicz, Kościół Najświętszej Marii Panny w Toruniu (Towarzystwo Naukowe w Toruniu, „Zabytki Polski Północnej” nr 10) (Toruń: TNT, 1998), 27-80; Adam Soćko, Układy emporowe w architekturze państwa krzyżackiego (Warszawa: Neriton, 2005), 309-312; Christofer Herrmann, Mittelalterliche Architektur im Preußenland. Untersuchungen zur Frage der Kunstlandschaft und geographie (Petersberg: Peter Imhof Verlag, 2007), 756-758.

8 In spite of Nawrocki's theory, it is possible, that the south wall of the church with the inner buttresses could be dated back to the mid- $14^{\text {th }}$ cent.; at the turn of $14^{\text {th }}$ this part of building has been probably only increased and vaulted.

9 Nawrocki, „Pofranciszkański kościół NMP”, 47-80; Nawrocki, „Kościół Mariacki”, 19-53; Nawrocki, Pofranciszkański kościół, 4-27. 
on the east side, covered with an ornate eight-pointed stellar vaulting on a vertiginous height of 27 meters. In accordance with the requirements of the monastic rule it had to be separated from the nave by an intermedium. There is no sources that would allow to establish whether the space of the choir was occasionally made available for the lay faithful as it was practiced in a number of mendicant churches in Europe ${ }^{10}$ or for instance at Torun Dominican Friars ${ }^{\prime 11}$. Its furnishing is preserved in remnants and some elements are uncertain.

The main element of the furnishing of interioris must have been a conventual altar fitted with holy relics and furnished with liturgical vessels (sanctuary appointments of the main altar were an exception from the rule of monastic poverty ${ }^{12}$ ) and lighting, and probably also with an antependium and a painting or a retable. It was however not the Torun Polyptych (fig. 3), now in collection of the Diocesan Museum in Pelplin, at least not in a form that we know today ${ }^{13}$. Analysing early-modern written sources, concerning unfortunately an already altered (compiled of several parts) retable ${ }^{14}$, one can assume that the Medieval main retable at the Franciscan Friars' was most probably a woodwork one with openings to hold the holy relics in its lower part; it was closed with wings that were (at least on the reverses) painted.

10 See: Monika Schmelzer, Der mittelalterliche Lettner im deutschsprachigen Raum: Typologie und Funktion („Studien zur Internationalen Architektur- und Kunstgeschichte“ 33) (Petersberg: Michael Imhof Verlag, 2004), 81-98, 150-151.

11 In an indulgence letter of the year 1392 one can read about a fourteen-day indulgence in return for saying five Pater noster at the high altar in the choir. Records concerning the history of the Dominican convent in Torun 1232-1762, Archiwum Diecezjalne w Pelplinie [Diocesan Archives in Pelplin], Monast. Tor. Dom. 1-2, 34r.

12 Matthias Untermann and Leonie Silberer, „Architektur franziskanischer Kirchen und Klosterbauten“, in Franziskus-Licht aus Assisi. Katalog zur Ausstellung im Erzbischöflichen Diözesanmuseum und im Franziskanerkloster Paderborn, ed. Christoph Stiegemann, Berndt Schmies, and Heinz Dieter Heimann (München: Hirmer Verlag, 2011), 141. See also artefacts belonging among the furnishing of Franciscan altars (chalices, pyxides, monstrances and vestments in the same catalogue, 343-352).

13 For the thorough analyses of the structure, technique and style see: Juliusz Raczkowski, Poliptyk Toruński. Studium zabytkoznawczo-konserwatorskie (Toruń: Wydział Sztuk Pięknych UMK, 2016).

14 The altar retable in the space of ecclesiae interioris has been described in the following sources: Script by Johannes Muck von Muckendorf (1637); Memoranda by Johann Baumgarten (1715-19); Inwentarz kościoła NMP i budynków klasztornych, spisany przy przejmowaniu ich przez Bernardynów (7-12 XII 1724), see, after earlier editions - „Aneks źródłowy” 1, in Raczkowski, Poliptyk Toruński, 191-192. 
It might have represented the northern row altar type (Ger. Reihenaltar) ${ }^{15}$. In the centre a scene of Coronation of the Virgin was placed with figures of saints to the sides (including Franciscan saint patrons: Clare, Francis, Anthony and Louis). Hypothetically, at least two of the panels that make today's Torun Polyptych can be associated with that structure because of its size and content ${ }^{16}$. The iconography of the main retable was probably distinctly related with the spirituality, passion mystic, Virgin Mary's cult and patronal Franciscan cults practiced by the friars. It was probably introduced to the church after erecting a final vaulting of the chancel, ca. 1400. What was earlier in this location remains unknown. Perhaps one should look at the main altar as a place for the oldest, Bohemian panels of the Polyptych ${ }^{17}$, of high artistic class and an elaborate program addressed to the learned, Franciscan recipients (fig. 4 : $a-b)^{18}$.

The Medieval décor of the grey friars' choir preserved in situ consists of a barely readable polychrome of the vaulting ca. 1400, displaying features of

15 Raczkowski, Poliptyk Toruński, 45-52; see also separately, on the retable of high altar exclusivly: Juliusz Raczkowski, „Średniowieczne retabulum ołtarza głównego u toruńskich franciszkanów. Na marginesie prac badawczo-konserwatorskich przy tzw. poliptyku toruńskim”, in Imagines pictae: Studia nad malarstwem gotyckim w Polsce, ed. Marek Walczak, and Wojciech Walanus („Studia z Historii Sztuki Średniowiecznej Instytutu Historii Sztuki Uniwersytetu Jagiellońskiego" 4) (Kraków: Societas Vistulana, 2016), 29-41.

16 Those would be double-sided panels with scenes painted on the obverses: Virgin Mary entering the Temple, The miracle of St Clare, Stigmatisation of St Francis, St Anna with Virgin Mary and Infant Jesus, and on reverses: Prayer in Gethsemane, The Taking of Christ, The Mocking of Christ, Crucifixion, Deposition from the Cross. Perhaps the wings were larger and contained one more row composed of square panels of the Torun Polyptych - the panel with scenes of Christ Carrying the Cross and The Swon of the Virgin on one side and Mater Misericordiae and St Louis of Toulouse on the other, the panel Christ before Pilate and Flagellation on one side and St Anthony preaching and Pieta on the other. In terms of the contents such composition is possible, however doubtful - considering different dimensions of the panels and their different structure. Raczkowski, Poliptyk Toruński, 21-25 as well as 101-116, 153 and 158.

17 For the detailed discussion see: Raczkowski, Poliptyk Toruński, 132-133. The panels might have fulfil a devotional function or make a part of the rood screen.

18 This is about four, originally one-sided panels, combined by B. Schmid in a form of two panels with representations from the Childhood of Christ and Quinitas on obverses. On the iconography see: Maria Michnowska, „Ze studiów nad XIV-wiecznym poliptykiem toruńskim”, Teka Komisji Historii Sztuki TNT 2 (1961): 121-212; Tadeusz Dobrzeniecki, „The Toruń Quinity in the National Museum of Warsaw", The Art Bulletin 26 (1964): 381-388; Tadeusz Dobrzeniecki, „Toruńska Quinitas”, Biuletyn Historii Sztuki 30, no. 3 (1968): 261-278; Adam S. Labuda, „Chrystus dwunastoletni - Bóg, Nauczyciel. Ze studiów nad retabulum franciszkanów toruńskich", in Nobile claret opus. Studia z dziejów sztuki dedykowane Mieczysławowi Zlatowi, ed. Lech Kalinowski, Stanisław Mossakowski, and Zofia Ostrowska-Kębłowska (Wrocław: Wydawnictwo UWr, 1998), 106-122. 
the International Style (representations of four female saints of whom only two have been identified - St Barbara, fig. 5, and St Mary Magdalene). Of the alleged elements of the choir furnishing, that perhaps were associated with religious life of the convent themselves a unique Seraph-Christ from early $15^{\text {th }}$ century preserved at the Bernardine Fathers' in Skępe (fig. 6) has to be mentioned ${ }^{19}$. It is unique in European scale, three-dimensional and entirely autonomic realisation of that theme (retable-top? devotional representation?), functioning independently from the scene of St Francis Receiving the Stigmata. Most probably it was designed for an exclusive sacred space (an oratory, a monastery cell, sacristy, or ecclesia interior).

Ecclesia exterior at Torun Franciscan Friars' comprised the body of the church, at least the nave and the south aisle (fig. 2: D). It is not known, to what extent the north aisle (fig. 2: B), created by incorporating the south part of the cloister to the church building, was available to the faithful (surely its original function was related with monastic life). Also the availability and functions of the north gallery is not clear.

The duality of space of ecclesiae fratrum and ecclesiae laicorum had been accentuated by the intermedium, clearly marking the two separate liturgical zones. Unfortunately, nothing is known either about the form or about the structure of the rood-screen. What is known is its width, that must have been limited to the width of the chancel: taking into consideration that the north aisle was separated by a wall and that there was an entrance leading from the then yard set in the east wall of the south aisle, it seems that developing the screen into a form of multi-field arcaded structure would not have been possible. Its outer perimeter is probably marked by the entrance to the socalled sacristy on the north side: most probably it had to be accessible from the outside of the screen (for functional reasons - see further on). Also a votive mural with a river boat and St Nicholas (1400) visible on the north wall must have belonged to the outer zone.

The passage from the nave to the choir could have been located on the axis of the rood-screen, or there were two passages on both sides of the chancel. The number and position of the rood-screen altars is today hard to establish (two altars on both sides, or - most probably - one altar on the

19 Association of the sculpture with Torun Franciscan Friars is purely hypothetical, but considering its dating and iconography - highly probable. It is possible, that the sculpture came to Skępe not directly form the Franciscan church but later, through the Torun Bernadine Fathers - after dissolution of their convent in 1817. 
axis). What draws attention in this context is the separateness of painted decoration of the first span from the east in the southern nave (fig. 7: a). This seems to be ideologically associated with the intermedium and with the liturgical centre of the church from which it is separated by north portal belonging to the outer cloisters (perhaps there was a procession pathway). Two massive figures of Archangels - Michael and Gabriel - intertwined with the cycle of monumental decorations of the south aisle seem to be stylistic somewhat later (ca. 1390-1400) then other painted representations of the cycle. They follow the general composition but are more softly painted and the architecture is more elaborate and lighter. There is also no connection between them either in terms of theme or of function. There is however a distinct relationship between them and the scene of Coronation of the Virgin-Ecclessia of a unique in Prussia, Italian iconography ${ }^{20}$ : enthroned figures of Christ and Virgin Mary are surrounded by nine angelic choirs (fig. 7: b). Besides, a mighty figure of St Michael on the east wall faces the south aisle and seems to be a "continuation” of the rood screen. So the space of east recess might have been related with the cult of angels and the essence of its unique program is combined with the celestial liturgy, the repetition of which is the eucharistic liturgy celebrated on the altar. Coronation of the Virgin the wedding of Christ to the Church - has been presented here as a liturgical mystery, adoration of God's throne, the image of the hymn Sanctus sung by the angelic choirs.

The layout, décor and function of the remaining space of laicorum at Torun Franciscan Friars' are to be analysed in a number of main aspects. First of all this is where the basic element of mendicant ministry was performed - the ad status preaching. This had its own, particular ethos and an overriding aim: in concordance with the ideals of Lateranum IV, it was inseparably bound with confession. It was to elicit repentance, encourage expiation and as a consequence - lead to alteration of the way of life, that is to conversion. The preachers' tasks hardly had a prevailing influence on the form of Franciscan Friars' architecture, nevertheless they were taken into consideration while planning the liturgical space. Thus in ecclesiae laicorum of Torun church the dominant west-east axis was shaken. The entrance was from the south, from the direction of the market square - at least until ex-

20 Alicja Karłowska-Kamzowa, „Włoskie źródła ikonograficzne malowidła Koronacji NMP z pofranciszkańskiego kościoła w Toruniu”, in Nobile claret opus, 123-132. 
tending the western part in late $14^{\text {th }}$ century: so the main portal would be the south one. The church yard was located on the south-east side, available from the St Mary Street and could have been used for occasional outdoor preaching. Transversal axis of the church was associated with the alleged location of the pulpit ${ }^{21}$ and the organ placed on a longitudinal gallery. It is worth mentioning, that in the space of ecclesiae exterioris not only activities resulting from the pastoral mission were concentrated, but also those resulting from the social position of the convent in the town. They had to compete for the faithful and donators with the Old Town parish church and with the Dominican Friars, whose convent was founded two decades later (1263) in the New Town. The space of the nave quickly reflected that situation. It was a venue of liturgy with alluring musical setting and crammed with altars that served their private founders. The Medieval baptismal font of quite rough octagonal form, preserved inside the main nave, can serve as an argument that they have performed also baptismal service ${ }^{22}$. The images present inside were engaged is service of preaching, private devotion and cults tended by the Franciscan Friars - especially the cult of Christ's Passion. Iconosphere of that interior, addressed chiefly to the representatives of town rabble, was abundant and expressive, sometimes even verging on a popular devotion.

The mendicants yoked music to their spiritual and pastoral program. The first ever organ in the Monastic State were those in Torun grey friars' church (1343). The instrument considerably enhanced attractiveness of ministry

21 Unfortunately there is no precise information on the location, material or the look of the pulpit at the Torun Franciscan Friars, but it had to be present in the space of $14^{\text {th }}$ cent. church from the beginning. It is known, that it was still used by the Protestants till the early $17^{\text {th }}$ cent.: Piotr Birecki, „Wyposażenie wnętrza kościoła Mariackiego w Toruniu w okresie Reformacji”, in Dzieje i skarby kościoła Mariackiego, 281-282, note 36. Most probably it was a wooden structure placed against one of the pillars. Assuming that introducing a new, Mannerists' pulpit a traditional location was maintained it could have been placed at the third pillar from the East on the north side.

22 A Mediaeval font, quite crudely shaped and devoid of any decoration, probably dated back into early $14^{\text {th }}$ cent. (?), is located on the north side in the western part of the church - that is in concordance with the Mediaeval tradition, but the localisation is probably secondary. Function of the font in the Mediaeval St Mary's church remains however an open question: the sacrament of baptism had been - in accordance with tradition and diocesan statutes a part of parochial obligation, but there is no written sources mentioning baptisms at Torun greyfriars'. Nevertheless one can assume that baptisms were given at least in the period, when the church provided pastoral ministry for the dwellers of extra muros suburbs, before definitive formation of parochial structure in Torun and normative regulations for the Chełmno Diocese. Perhaps also later the parochial obligation in this respect had not been respected. 
exercised by them ${ }^{23}$. Even the $16^{\text {th }}$-century chronicler David reported, that the organ attracted crowds of people wanting to watch it and to listen to the music ${ }^{24}$. The instrument, until extending the northern gallery, must have functioned in the church space from the late $13^{\text {th }}$ century, most probably on some elevated, overhung wooden structure. The location of Medieval organ is indirectly confirmed by location of the present, early-modern instrument - let us remind, that according to Adam Soćko ${ }^{25}$ it was the musical function that had determined the character of alterations of the church in this section: a gallery housing the singing choir (musicians' gallery), would have made an additional liturgical focal point in the church. Such location would have also been the most appropriate in terms of acoustics and would have allowed to display the artistic form of the instrument to its best.

The analysis of elements of iconosphere of the church indicates, that the friars were aware of and made use of the potential of image - both for teaching and for inspiring their listeners to deeper religious experience leading to conversion and expiation. Among the works of the easiest perception and the strongest impact one should count mural paintings. The church of Torun Franciscan Friars is in this aspect particularly rich, however the full program of murals is hard to reconstruct. Undoubtedly, the largest realisation among the mendicant mural polychromes (and even in Central European mural painting in general) is the cycle on the south side of the church. This is a series of full-length images of saints under canopies as well as representations of Our Lady of Sorrows and Christ at the Column, generally interpreted as a triumphal rendering of Communio Sanctorum (fig. 8), containing angelolog-

${ }^{23}$ Information on the organ being made by a Franciscan monk is found in an $18^{\text {th }}$ cent. Franciscan chronicle: Archiwum Diecezjalne w Pelplinie, Monastica Torun - Franciszkanie 1, sygn. Tor. Franc. 1, Archivum Conventus Thorunensis ad Mariam Annunziatam 1239-1792, $18^{\text {th }}$ cent., The chronicle, original documents and copies, p. 3, entry for the year 1343: „Religiosus quidem ordinis Minorum fecit elaboravitque organa prima Thoruny in Ecclesia Sancta Mariae cum 22 fistulis more moderno trahebantur folloes, quod tunc temporis quid rarum et peculiare fuit in ista Regione". Location of the instrument from 1343 in the Blessed Virgin Mary's church has been assumed by: Werner Renkewitz and Jan Janca, Geschichte der Orgelbaukunst in Ost- und Westpreußen von 1333 bis 1944, vol. 1 („Bau- und Kunstdenkmäler im Östlichen Mitteleuropa“, Vol. 2) (Würzburg: Verlag Weidlich, 1984), 2-5; Soćko, Układy emporowe, 310-311, as well as Krantz-Domasłowska, „Przestrzeń liturgiczna”, 161.

24 Julius Emil Wernicke, Geschichte Thorns aus Urkunden, Dokumenten und Handschriften, Bd. 1-2 (Thorn: Kommissionsverlag von E. Lambeck, 1842), vol. 1, 64.

25 Soćko, Układy emporowe, 312, even believes, that rebuilding the Franciscan church to the form of the so called third church wit a gallery in the north aisle was associated with the idea of transforming the interior into a sort of a „concert hall”. 
ical motifs and elements of the cult of Christ's Passion, set in the mysticism of St Bonaventure, with an indication towards some local cults ${ }^{26}$. What draws attention in this composition is the pose of characters - all of them, thanks to slight turns of bodies or tilts of heads, are directed towards the nave, they gaze at symbols or attributes or seek a direct eye contact with the viewers. They act within the space of church as a distinct accord, regardless of the point of view in the nave (but they are almost invisible from the chancel and only partly perceivable from the gallery). This, in a way, dictates their interpretation: undoubtedly their main recipients were the laity gathered in the nave and in the south aisle. Christ at the Column and Our Lady of Sorrows act as an incentive to contemplate the Passion and to expiate for sins (il. 9: a). St John the Baptist (fig. 9: b) „exhorts” to conversion emphatically pointing out to the Lamb and the presence of Mary Magdalene (beatissima peccatrix) enhances the idea of expiation. St Elisabeth (here without symbols of nobility but rather as a tertiary with attributes of charity), might have been a model for practicing alms. Of course, each of those representations can be discussed in terms of individual matters (associated with Franciscan spirituality and mysticism, as suggested by Błażejewska ${ }^{27}$ ). However it seems, that considered together those images make a monumentalised appeal to the faithful. They make a set of visualised rhetorical figures, instruction on forms of vocation and devotion, that might have been utilised by Franciscan Friars in preaching the sermons (which would have a parallel in mendicant preaching tradition of German circle, e.g. Berthold of Regensburg ${ }^{28}$ ). Leaving out its probable homiletic function, Franciscan Collegium Sanctorum expressed the general ecclesiological idea: standing before those representations the Medieval viewer stood in front of the walls of Celestial Jerusalem looking through the „windows" opening behind the saints at the transcendent reality. Even today, the murals are a dominant accent of liturgical space, they make a complete, multithreaded assembly of an undeniable artistic class. It seems that their Medieval users were aware of those values: except for minor additions with-

26 Among others: Błażejewska, „Czternastowieczny wystrój”, 73-80; Krantz-Domasłowska, „Przestrzeń liturgiczna”, 159-160.

27 Błażejewska, „Czternastowieczny wystrój”, 73-80.

28 Peter P. Loewen, „The conversion of Mary Magdalene”, in Speculum Sermonis. Interdisciplinary Reflections of the Medieval Sermon, ed. Georgiana Donavin, Cary J. Nederman, and Richard Utz („Disputatio”, vol. 1) (Turnhout: Brepols, 2004), 242, 246. 
in the cycle itself ${ }^{29}$ and on the north wall ${ }^{30}$, no other element of décor ever competed with that unusual realisation. Its usus had been broken only by the Protestants, who whitewashed the walls and introduced new elements of burghers' memoria (epitaphs, gravestones).

An important tool of eliciting penitential emotions was a strong, emotive engagement of the faithful in the cult of Christ's Passion. It is not a coincidence, that particular panels of the Torun Polyptych, of diverse origin, are so strongly focused on Lord's Passion. The cult of Passion reached its apogee at the turn of $14^{\text {th }}$ century, going side by side with stimulation of a spontaneous, mass devotion of the laity, demonstrated in Prussian towns mostly by the layers of rabble and plebs. It was the Franciscan Friars who propagated Passion mystery plays and liturgical dramas of the Paschal Triduum. In the western part of Our Lady's church most probably since the turn of $14^{\text {th }}$ century existed probably a two-span chapel of the Holy Sepulchre (fig. 2: C) - a separate place of the temporary Easter Sepulchre and possibly of a permanent Passion devo$\operatorname{tion}^{31}$. Associated with this space was perhaps a monumental wooden sculpture of Christ in the Tomb, made in a Torun workshop ca. $1400^{32}$ (now at the Torun Museum). Used in rituals, it could have been also an object of devotion. In an appalling way it astounds with horror of rigor mortis, spattered with „blood” as in the writings of St Bonaventure. In terms of the power of impact it is one of the most expressive Passion sculptures known in the Medieval Prussia.

The monastic ideals and Passion mysticism, high-quality intellectual formation, pastoral disposition and skilfully exercised religious propaganda, gave the mendicants vast popularity and made them highly competitive with

29 Murals depicting Annunciation ( $3^{\text {rd }}$ quarter of $14^{\text {th }}$ cent.) and The Magi (ca. 1350) on the inner buttress in the third span from the east on the south side, beneath the image of St Christopher; the scene with St Hedwig (late $14^{\text {th }}$ cent.) on the first inner buttress from the east on the south side, beneath the image of St John the Baptist.

30 Murals depicting St Francis (?) and St Mary Magdalene in Ecstasy.

31 See Bogumiła J. Rouba et al., „Kaplica Grobu Pańskiego w toruńskim kościele Mariackim - wyniki badań konserwatorskich”, in Dzieje i skarby kościoła Mariackiego, 503-526; Krantz-Domasłowska, „Przestrzeń liturgiczna”, 167.

32 On the sculpture itself see: Monika Jakubek-Raczkowska, Juliusz Raczkowski, „Gotycka figura Chrystusa w Grobie i jej miejsce w przestrzeni liturgicznej kościoła franciszkanów w Toruniu”, in Dzieje i skarby kościoła Mariackiego, 181-202; on the Torun woodcarvers' workshop where the sculpture was made: Juliusz Raczkowski, Monika Jakubek-Raczkowska, „Gotyckie rzeźby z kościoła w Świerczynkach. Przyczynek do badań nad średniowiecznym dziedzictwem Torunia”, in Stare i nowe dziedzictwo Torunia, ed. Juliusz Raczkowski („Studia i materiały z dziedzictwa kulturowego Torunia i regionu", V. 1) (Toruń: Wydział Sztuk Pięknych UMK, 2013), 108-125. 
parish churches. As it was mentioned before, the convent of Torun Franciscan Friars had been attractive as a place of burial and concern with salvation for the richest patriciate. There are early-modern descriptions of gravestones ${ }^{33}$ of wealthy families located in its space - von Allen ${ }^{34}$, Werle ${ }^{35}$ and Wale $\mathrm{e}^{36}$. Similar to the grave plate of von Soest spouses in the Old Town parish church, they presented full-length images of the deceased, dressed in sumptuous attire, enriched with subsidiary motifs, attributes, crests and inscriptions. Being probable imports from Bruges they gave testimony of the wealth and prestige of Torun burghers and were a material proof of connections of the convent with the Old Town patriciate.

Popularity of the church caused also gradually progressing „privatisation” of the space of laicorum. Undoubtedly there were numerous side altars associated with private liturgical foundations, but unfortunately very little is known about them. In 1401 St Andrew's altar belonging to the fraternity of fishermen is mentioned ${ }^{37}$, and in the Chronicle of Torun Bernardine Fathers before 1730 one can read about St Francis' altar from an earlier period ${ }^{38}$. The use of spaces between inner buttresses in the Blessed Virgin Mary's church as chapels has not been confirmed, however one is entitled to make such assumptions. Torun town mayor Jan Stroband, whose epitaph is located in the space between the buttresses on south wall in the second span from the East, in his testament of the year 1531 expressed the wish to be buried „zu den grauen brudern fur dem S. Lorentz Altar” („,at grey friars’ before St Laurent's altar”) ${ }^{39}$.

Private donors were commemorated by crest-shields: a good example being preserved in the relics of window glazing ${ }^{40}$. Particularly unique in terms

33 The grave plates were mentioned in old descriptions of the church interior - by Jan Muck von Muckendorf (1637), by Efraim Praetorius (1714), by Jan Baumgarten (1715-19) and in the „Torun Chronicle” (Thornische Chronica) by Zernecke published in print (1727). See Marta Czyżak, „Późnogotyckie płyty nagrobne w kościele Mariackim w Toruniu”, in Dzieje i skarby kościoła Mariackiego, 223-246.

34 Grave plates of Gerhard ( $\uparrow 1371)$, Margaretha ( $† 1367)$ and Conrad ( $\uparrow 1371)$ von Allen; first row of grave plates, at the entrance to the chancel.

35 Grave plate of Heinrich and Christina Werle ( $\dagger 1373), 7^{\text {th }}$ row of grave plates, next to the pulpit.

36 Grave plate of Ludolf Wale and his sister Margaretha ( $\dagger 1381), 9^{\text {th }}$ row of grave plates.

37 Oliński, Fundacje mieszczańskie, 513.

38 Kamil Kantak, „Kronika bernardynów toruńskich”, Roczniki Towarzystwa Naukowego w Toruпіи 32 (1925): 117.

39 „Thorner Denkwürdigkeiten von 1345-1547“, ed. Albert Voigt (Mitteilungen des Coppernicus-Vereins 13) Thorn: Kommissionsverlag von E. Lambeck 1904, 174.

40 Of the surviving fragments (presently in the District Museum in Toruń) only the von Rockendorf crest was identified. 
of iconography is a painting on the north wall of the main nave near the chancel entrance, with a river sailing boat above which hover St Nicholas and - most probably - Virgin Mary. In terms of iconography this is a synthesis of pictorial motifs emphasising the risk of incidents on the water ${ }^{41}$ and expression of hope in the protection of saint patrons. The painting may be a material proof of the associations of Franciscan convent with the fraternity of Vistula fishermen ${ }^{42}$. As a good example of the liturgical use of the church space the south-western span has to be mentioned (fig. 2: E). Equipped with its own consecration crosses, it can be seen as a separate chapel. It is decorated with a votive representation of St Barbara and kneeling donors (poorly preserved) on the western wall and a simultaneous scene, depicting The Prayer in Gethsemane and Christ Carrying the Cross (fig. 10) on the southern wall. Especially the Passion scene is of great importance as a testimony of private devotion flourishing in Prussian towns in early $15^{\text {th }}$ century, performed with relish by the laity in the space of mendicant churches ${ }^{43}$.

The peculiar, private „annexation” of mendicant churches by lay people is also confirmed by the design of the so called „sacristy” (fig. 2: F) erected at Our Lady's church still in late $13^{\text {th }}$ century. It was built as a vaulted, chapel-like space, terminated polygonally on the East, consecrated at least twice ${ }^{44}$, equipped with a piscina and a burial crypt. The walls are decorated with tracery polychromes and medallions with Apostles' effigies and consecration crosses. The suspended keystones (fig. 11) carry two separate representations of a lay couple ${ }^{45}$ and the coat-of-arms of a still unidentified family (families? ${ }^{46}$. Most probably one deals here with a burghers' liturgical foundation

${ }^{41}$ Monika Jankiewicz-Brzostowska, Timor Maris. Lęk człowieka przed żywiołem wodnym w gotyckim malarstwie polskim (Gdańsk: Muzeum Morskie, 2005), 129-143.

42 The agreement concluded on St Francis feastday, October $4^{\text {th }} 1401$ - the fishermen brotherhood agreed to pay certain annual fee in return for daily mass celebration. Oliński, Fundacje mieszczańskie, 512-513.

43 More on that mural: Juliusz Raczkowski, „Najnowsze odkrycia w zakresie gotyckiego malarstwa ściennego w Prusach i ich znaczenie dla badań nad sztuką regionu”, in Homo Creator et Receptor Artium. Księga pamiątkowa Księdzu Profesorowi Stanisławowi Kobielusowi ofiarowana, ed. Małgorzata Wrześniak (Warszawa: Wydawnictwo UKSW, 2010), 96-98.

44 The six preserved Apostles medallions in the style of the mid- $14^{\text {th }}$ cent. were painted on the plaster, which covered an earlier set of consecration crosses painted directly on the brick wall (13 $3^{\text {th }}$ cent.?).

45 A man with early $14^{\text {th }}$-cent. hairstyle on the north side, and a woman with a headscarf and wimple on the south side.

46 All the keystones are overpainted, so the original colours of the coat-of-arms are not known. The crest with three hunting horns on a shield (originally probably blue) belonged to an uni- 
- unfortunately not confirmed in written sources. That would resemble the situation in St Catherine's church in Lübeck, where the burghers (Strobuk and Crispin families) have founded chapels destined as family memoria ${ }^{47}$ on both sides of the chancel, set beneath the floor-level of ecclesiae fratrum.

Architectonic form and the basic - distinctive against the background of other mendicant churches - furnishing of the Blessed Virgin Mary's church in Torun emerged in early $15^{\text {th }}$ century. Later period - almost till the turn of that century - is lacking artistic testimonies that would present intellectual and economical condition of the convent ${ }^{48}$. Perhaps this is an indication of spiritual crisis within the convent, but that is denied by constant grey friars' activities in town, confirmed by written sources ${ }^{49}$. So it seems more probable, that previous abundance and diversity of images that filed the church interior had been so attractive and so suitable for both the mendicant ministry and the devotional needs, that later the space was not either enriched or actualised in terms of religious contents and artistic fashions. Only the almost complete lack of any proofs of burghers' care for the church is astonishing. Perhaps the later furnishing, related with side altars, consisted of movable property - altar retables, vessels etc. Those might have been dissipated during the Protestant period in the church itself ${ }^{50}$ and beyond it; there is also information on damage in the church made during an uproar in $1525^{51}$.

dentified Torun patriciate family and was represented also on the wooden shield in the early-modern „Pantheon” in the church chancel; see Krzysztof Mikulski, Tarcze herbowe z kościoła Mariackiego w Toruniu (Warszawa: DiG, 2015), 45-46, 61-62. The other keystone could be also interpreted as a coat-of-arms. Among the early-modern set of shields in the chancel there were two rose-crest representations, belonging to the Brelen family - white rose on a red shield, see Marian Gumowski, Herbarz patrycjatu toruńskiego (Toruń: TNT, 1980), 40-42; Mikulski, Tarcze, 155-156, and golden rose on a red-and-white shield, see Mikulski, Tarcze, 75-76 (also as: von Pape).

${ }^{47}$ Manfred Finke, Unesco Weltkulturerbe Altstadt von Lübeck: Stadtdenkmal der Hansezeit (Lübeck: Wachholtz, 2006), 184; Heike Trost, Die Katharinenkirche in Lübeck: franziskanische Baukunst im Backsteingebiet. Von der Bettelordensarchitektur zur Bürgerkirche („Franziskanische Forschungen “, Heft 47) (Kevelaer: Butzon \& Bercker, 2006), 190-205.

48 It is known, that during the thirteen-years' war Franciscan Friars had lend the town the convent silverware (a large crucifix and 6 chalices) for a receipt. Urkundenbuch des Bisthums Culm, ed. Carl Peter Woelky, vol. 1 (Danzig: Commissionsverlag von Theodor Bertling, 1885), no. 618.

49 Among others testamentary documents, confirmations of brotherhood agreements, financial liabilities, see Oliński, Fundacje mieszczańskie, 509-515.

50 For example panels from the main altar mentioned by early-modern authors, depicting Fathers of the Church (wrongly identified by Baugarten 1715-19 as „quatuor Evangeliste in habitu Cardinaliut et Episcoporum")', could have been a late Gothic element.

51 „Thorner Denkwürdigkeiten“, 156. 
Chronologically next (and the last Franciscan) set of church furnishing dates back to the years 1480-1500. Its artistically most attractive element is a Crucifix (presently on the north wall at the entrance to the chancel), that - supposedly - used to be previously connected with the Franciscan roodscreen (fig. 12). In the $2^{\text {nd }}$ half of $16^{\text {th }}$ century it had been adapted by the Protestants to arrange a rood-beam ${ }^{52}$, from which it was only removed by the Bernardine Fathers in 1731. The sculpture, based on northern ${ }^{53}$ or South-German $^{54}$ models, displays a very high artistic class and its relations with other artworks preserved in Torun ${ }^{55}$ seems doubtful. The literature univocally emphasises idealism of that representation: harmony, grace, aesthetisation of form and stylisation of proportions endeavouring divine perfection ${ }^{56}$, while it is rather oriented towards an utter naturalism. Realistically modelled Christ's body is extremely strained and parched; his expressive, painful face is framed with stiff, as if glued with sweat strands of hair. It seems to be the last in Torun, artistic testimony of traditional, doloristic Franciscan spirituality of deeply mystical background, introduced to the church almost on the eve of secularisation of the convent. In the same time a large assemble of exquisite carpentry emerged: carved parapets of the gallery and Late-Gothic wood-

52 The crucifix, facing the nave, had been combined with another one, facing the chancel; the assisting figures also faced the nave. „In ipso chori ingresu supra trabem altitudinis ad duas perticas transversim parietibus immisam, videtur figura Salvatoris crucifixi in ligno crucis pendentis, ab una parte in choro altare versus, cum subscriptione: Mir macht die Lieb so viel und grosse Plagen Sie bloss nicht meine Schuld, hat mich ans Creutz geschlagen. Sub cruce: Anno 1563. Altera vero ad reliquaam templi partem spectans, prisci laboris, adstantibus ab utroque latere, Beatissimae Virginis atque s. Johannis Evangeliste staturis in ipsa trabesequens renovate inscriptio Hic mea me pietas lingo confixit in alto, Hic me solus amor, non mea culpa tenet. 1675". Quoted after Bogusław Dybaś and Marek Farbiszewski, Miscellanea źródłowe do historii kultury i sztuki Torunia („Źródła i materiały do dziejów sztuki polskiej” 22, ed. Marian Arszyński) (Wrocław, Warszawa, Kraków, Gdańsk, Łódź: Wydawnictwo Ossolineum, 1989), 122-123.

53 German under the Netherlands' influence, e.g. Domasłowski and Jarzewicz, Kościół Najświętszej Marii Panny, 105.

54 Andrzej Woziński, „Rzeźba drewniana na Pomorzu Wschodnim w latach 1450-1550” (doctor's dissertation, Uniwersytet im. Adama Mickiewicza in Poznań, 1996), 305-316, cat. no. 469; Andrzej Woziński, „Artystyczne i ideowe aspekty późnogotyckiego krucyfiksu w pofranciszkańskim kościele”, in Dzieje i skarby kościoła Mariackiego, 220-221.

55 For example the statue of Christ scourged from the Copernicus chapel of St Johns' church in Torun or a sculpted group of Pietas Domini from the parish church in Świerczynki near Toruń.

56 This is the way the sculpture was analysed by Woziński, „Artystyczne i ideowe aspekty”, 203-221. 
work stalls of late $15^{\text {th }}$ century ${ }^{57}$. The latter make a particularly abundant and prestigious element of the choir space. Originally they must have covered the whole length of the chancel and most probably the western wall of the rood-screen; they could have consisted of up to 60 seats. This is to much for the then number of convent members: perhaps the associates of spiritual Franciscan fraternity were admitted to the communal prayer ${ }^{58}$.

Thus quite late - almost at the dawn of Reformation in Torun - substantial changes were made in the church interior: the gallery in the aisle was completed, the space of the choir reorganised, the rood-screen was adorned with the Crucifix. In the same time some parts of painted decoration of the cloister vaulting were executed by town workshops. Ornamental, floral decoration of walls and vaulting were up to date - similar compositions are preserved on the pillars of south aisle of the Old Town parish church and in numerous dwelling interiors in Torun (No. 15 Szczytna Street, No. 22 Łazienna Street, No. 7 Wielkie Garbary Street). This may prove that the convent was still numerous, buoyant and wealthy enough to undertake such enterprises - or (more likely) the artworks were founded by the town council.

To conclude: at the turn of $14^{\text {th }}$ and in early $15^{\text {th }}$ century the Franciscan liturgical space of St Mary's church was fully developed and adjusted to the mission and ministry of the Order of Friars Minor, equipped with altars, most important furniture and numerous paintings used in pastoral ministry and in encouraging lay piety. Décor and furnishing of ecclesiae fratrum are from today's perspective much less palpable. Ecclesia laicorum is in that respect much better preserved - in spite of structural alterations and transformations of décor resulting from denominational and functional changes. Material sources, though not so numerous, significantly complement a skimpy archival base related with functioning of one of the most significant Prussian convents in Middle Ages.

Translated by Joanna M. Arszyńska

7 Dating after: Maria Beek-Goehlich, Die mittelalterlichen Kirchengestühle in Westpreußen und Danzig („Bau- und Kunstdenkmäler des Deutschen Ostens“, Reihe B, Bd. 4) (Stuttgart: Kohlhammer, 1961), 77-98. The scholar has rejected the possibility, that some parts of the stalls were made in the first quarter of $15^{\text {th }}$ century (as it is assumed in older literature), she also attributed the tracery-decorated gallery parapets in the Franciscan church and the seats preserved in the Copernicus chapel in St Johns' church in Torun (ca. 1500 r.) to the same workshop.

58 Beek-Goehlich, Die mittlelaterlichen Kirchengestühle, 77-98. 


\section{Bibliography}

\section{Sources:}

Archiwum Diecezjalne w Pelplinie [Diocesan Archives in Pelplin], Monastica Torun Franciszkanie 1, sygn. Tor. Franc. 1, Archivum Conventus Thorunensis ad Mariam Annunziatam 1239-1792, XVIII w., Kronika, dokumenty w oryginale i kopiariusz. Archiwum Diecezjalne w Pelplinie [Diocesan Archives in Pelplin], Monast. Tor. Dom. 1-2, Akta odnoszące się do dziejów klasztoru Dominikanów w Toruniu, 1232-1762. Zernecke, Jacob Heinrich. Thornische Chronica in welcher die Geschichte dieser Stadt von MCCXXI bis MDCCXXVI aus bewehrten Scribenten und glaubwürdigen Documentis zusammen getragen worden. Aufl. 2. Berlin: Haude, Ambrosius, 1727.

\section{Publications:}

Beek-Goehlich, Maria. Die mittelalterlichen Kirchengestühle in Westpreußen und Danzig („Bau- und Kunstdenkmäler des Deutschen Ostens“, Reihe B, Bd. 4). Stuttgart: Kohlhammer, 1961.

Birecki, Piotr. „Wyposażenie wnętrza kościoła Mariackiego w Toruniu w okresie Reformacji”. In Dzieje i skarby kościoła Mariackiego w Toruniu. Materiały z konferencji przygotowanej przez toruński oddział SHS oraz IZiK UMK, Toruń 14-16 kwietnia 2005, ed. by Katarzyna Kluczwajd, 275-294. Toruń: SHS, 2005.

Błażejewska, Anna. „Czternastowieczny wystrój kościoła Mariackiego w Toruniu: duchowość franciszkańska a pobożność miejska”. In Dzieje i skarby kościoła Mariackiego $w$ Toruniu. Materiały z konferencji przygotowanej przez toruński oddział SHS oraz IZiK UMK, Toruń 14-16 kwietnia 2005, ed. by Katarzyna Kluczwajd, 55-85. Toruń: SHS, 2005.

Czyżak, Marta. „Późnogotyckie płyty nagrobne w kościele Mariackim w Toruniu”. In Dzieje i skarby kościoła Mariackiego w Toruniu. Materiały z konferencji przygotowanej przez toruński oddział SHS oraz IZiK UMK, Toruń 14-16 kwietnia 2005, ed. by Katarzyna Kluczwajd, 223-246. Toruń: SHS, 2005.

Dobrzeniecki, Tadeusz. „The Torun Quinity in the National Museum of Warsaw”. The Art Bulletin 26 (1964): 381-388.

Dobrzeniecki, Tadeusz. „Toruńska Quinitas”. Biuletyn Historii Sztuki 30, no. 3 (1968): 261-278.

Domasłowski, Jerzy, and Jarosław Jarzewicz. Kościół Najświętszej Marii Panny w Toruniu (Towarzystwo Naukowe w Toruniu, „Zabytki Polski Północnej” 10). Toruń: Wydawnictwo TNT, 1998.

Dybaś, Bogusław, and Marek Farbiszewski. Miscellanea źródłowe do historii kultury i sztuki Torunia („Źródła i materiały do dziejów sztuki polskiej” 22, ed. Marian Arszyński). Wrocław, Warszawa, Kraków, Gdańsk, Łódź: Wydawnictwo Ossolineum, 1989. 
Finke, Manfred. Unesco Weltkulturerbe Altstadt von Lübeck: Stadtdenkmal der Hansezeit. Lübeck: Wachholtz, 2006.

Gumowski, Marian. Herbarz patrycjatu toruńskiego. Toruń: TNT, 1980.

Herrmann, Christofer. Mittelalterliche Architektur im Preußenland. Untersuchungen zur Frage der Kunstlandschaft und -geographie. Petersberg: Peter Imhof Verlag, 2007.

Jakubek-Raczkowska, Monika, and Juliusz Raczkowski. „Gotycka figura Chrystusa w Grobie i jej miejsce w przestrzeni liturgicznej kościoła Franciszkanów w Toruniu”. In Dzieje i skarby kościoła Mariackiego w Toruniu. Materiały z konferencji przygotowanej przez toruński oddział SHS oraz IZiK UMK, Toruń 14-16 kwietnia 2005, ed. by Katarzyna Kluczwajd, 181-202. Toruń: SHS, 2005.

Jakubek-Raczkowska, Monika, and Juliusz Raczkowski. „Mendykancki dialog z wiernymi w sztuce wielkich miast państwa zakonnego w Prusach na przykładzie klasztorów ziemi chełmińskiej w XIV i XV wieku”. In Katedra, ratusz, dwór. Wielkie miasta a władza świecka i kościelna w kulturze średniowiecznej Europy. Materiały XXXIII Seminarium Mediewistycznego im. Alicji Karłowskiej-Kamzowej, 29 listopada-1 grudnia 2012 w Poznaniu, ed. by Jacek Kowalski, and Tomasz Ratajczak, 371-399. Poznań: PTPN, 2014.

Jankiewicz-Brzostowska, Monika. Timor Maris. Lęk człowieka przed żywiołem wodnym w gotyckim malarstwie polskim. Gdańsk: Muzeum Morskie, 2005.

Kantak, Kamil. „Kronika bernardynów toruńskich”. Roczniki Towarzystwa Naukowego w Toruniu 32 (1925): 103-134.

Karłowska-Kamzowa, Alicja. „Włoskie źródła ikonograficzne malowidła Koronacji NMP z pofranciszkańskiego kościoła w Toruniu”. In Nobile claret opus. Studia z dziejów sztuki dedykowane Mieczysławowi Zlatowi, ed. by Lech Kalinowski, Stanisław Mossakowski, and Zofia Ostrowska-Kębłowska, 123-132. Wrocław: Wydawnictwo UWr, 1998.

Krantz-Domasłowska, Liliana. „Hala hali nierówna i nie tylko. Próba wpisania kościoła Mariackiego w krajobraz architektoniczny średniowiecznego Torunia”. In Dzieje i skarby kościoła Mariackiego w Toruniu. Materiały z konferencji przygotowanej przez toruński oddział SHS oraz IZiK UMK, Toruń 14-16 kwietnia 2005, ed. by Katarzyna Kluczwajd, 87-109. Toruń: SHS, 2005.

Krantz-Domasłowska, Liliana. „Przestrzeń liturgiczna czternastowiecznego kościoła Franciszkanów w Toruniu”. In Album Amicorum. Między Wilnem a Toruniem. Księga pamiątkowa dedykowana prof. Józefowi Poklewskiemu, ed. by Piotr Birecki, Elżbieta Basiul, Juliusz Raczkowski, Małgorzata Wawrzak, 153-168. Toruń: Wydawnictwo Naukowe UMK, 2008.

Labuda, Adam S. „Chrystus dwunastoletni - Bóg, Nauczyciel. Ze studiów nad retabulum franciszkanów toruńskich”. In Nobile claret opus. Studia z dziejów sztuki dedykowane Mieczysławowi Zlatowi, ed. by Lech Kalinowski, Stanisław Mossakowski, and Zofia Ostrowska-Kębłowska, 106-122. Wrocław: Wydawnictwo UWr, 1998. 
Loewen, Peter P. „The conversion of Mary Magdalene”. In Speculum Sermonis. Interdisciplinary Reflections of the Medieval Sermon, ed. by Georgiana Donavin, Cary J. Nederman, and Richard Utz („Disputatio”, vol. 1), 235-258. Turnhout: Brepols, 2004.

Michnowska, Maria. „Ze studiów nad XIV-wiecznym poliptykiem toruńskim”. Teka Komisji Historii Sztuki TNT 2 (1961): 121-212.

Mikulski, Krzysztof. Tarcze herbowe z kościoła Mariackiego w Toruniu. Warszawa: DiG, 2015. Mroczko, Teresa. Architektura gotycka na ziemi chełmińskiej. Warszawa: PWN, 1980.

Mroczko, Teresa. „Programy architektoniczne zakonów żebrzących na ziemi chełmińskiej w XIII i XIV wieku”. In Sztuka i ideologia XIV wieku w Polsce. Materiały sympozjum Komitetu Nauk o Sztuce PAN Warszawa, 29 i 30 listopada 1973, ed. by Piotr Skubiszewski, 317-347. Warszawa: SHS, 1975.

Mroczko, Teresa, and Andrzej Włodarek. „Kościół pw. Panny Marii, franciszkanów”. In Architektura gotycka w Polsce, ed. by Teresa Mroczko, and Marian Arszyński („Dzieje sztuki polskiej” Vol. 2). Vol. 2 Katalog zabytków, ed. by Andrzej Włodarek, 243. Warszawa: PWN, 1995.

Nawrocki, Zbigniew. „Kościół Mariacki w Toruniu - budowa i przebudowy w świetle odkryć w ostatnim ćwierćwieczu”. In Dzieje i skarby kościoła Mariackiego w Toruniu. Materiały z konferencji przygotowanej przez toruński oddział SHS oraz IZiK UMK, Toruń 14-16 kwietnia 2005, ed. by Katarzyna Kluczwajd, 19-53. Toruń: SHS, 2005. Nawrocki, Zbigniew. „Pofranciszkański kościół NMP w Toruniu. Próba rekonstrukcji faz budowy”. Acta Universitatis Nicolai Copernici, Zabytkoznawstwo i Konserwatorstwo 2 (1966): 47-80.

Nawrocki, Zbigniew. Pofranciszkański kościół p.w. Wniebowzięcia Najświętszej Marii Panny $w$ Toruniu. Toruń: Parafia NMP, 2006.

Oliński, Piotr. Fundacje mieszczańskie $w$ miastach pruskich $w$ okresie średniowiecza i na progu czasów nowożytnych (Chełmno, Toruń, Elblag, Gdańsk, Królewiec, Braniewo). Toruń: Wydawnictwo Naukowe UMK, 2008.

Oliński, Piotr. „Rola średniowiecznych bractw religijnych w życiu miejskim na przykładzie toruńskiego bractwa kaletników, torebkarzy i rękawiczników”. In Studia nad dziejami miast i mieszczaństwa w średniowieczu. T. 1, collective editor, 77-91. Toruń: Wydawnictwo UMK, 1996.

Raczkowski, Juliusz. „Najnowsze odkrycia w zakresie gotyckiego malarstwa ściennego w Prusach i ich znaczenie dla badań nad sztuką regionu”. In Homo Creator et Receptor Artium. Księga pamiątkowa Księdzu Profesorowi Stanisławowi Kobielusowi ofiarowana, ed. by Małgorzata Wrześniak, 89-104. Warszawa: Wydawnictwo UKSW, 2010.

Raczkowski, Juliusz. Poliptyk Toruński. Studium zabytkoznawczo-konserwatorskie. Torun: Wydział Sztuk Pięknych UMK, 2016.

Raczkowski, Juliusz. „Średniowieczne retabulum ołtarza głównego u toruńskich franciszkanów. Na marginesie prac badawczo-konserwatorskich przy tzw. poliptyku toruńskim”. In Imagines pictae: Studia nad malarstwem gotyckim w Polsce, ed. by Marek Walczak, and Wojciech Walanus („Studia z Historii Sztuki Średniowiecznej 
Instytutu Historii Sztuki Uniwersytetu Jagiellońskiego” 4), 29-41. Kraków: Societas Vistulana, 2016.

Raczkowski, Juliusz, and Monika Jakubek-Raczkowska. „Gotyckie rzeźby z kościoła w Świerczynkach. Przyczynek do badań nad średniowiecznym dziedzictwem Torunia”. In Stare i nowe dziedzictwo Torunia („Studia i materiały z dziedzictwa kulturowego Torunia i regionu”, t. 1), ed. by Juliusz Raczkowski, 108-125. Toruń: Wydział Sztuk Pięknych UMK, 2013.

Renkewitz, Werner, and Jan Janca. Geschichte der Orgelbaukunst in Ost- und Westpreußen von 1333 bis 1944. Bd. 1 („Bau- und Kunstdenkmäler im Östlichen Mitteleuropa“, Bd. 2). Würzburg: Verlag Weidlich, 1984.

Rouba, Bogumiła J., Jolanta Korcz, Ludmiła Tymińska, Agnieszka Wiktoruk, Sławomir Majoch, and Michał Witkowski. „Kaplica Grobu Pańskiego w toruńskim kościele Mariackim - wyniki badań konserwatorskich”. In Dzieje i skarby kościoła Mariackiego $w$ Toruniu. Materiały z konferencji przygotowanej przez toruński oddział SHS oraz IZiK UMK, Toruń 14-16 kwietnia 2005, ed. by Katarzyna Kluczwajd, 503-526. Toruń: SHS, 2005.

Schmelzer, Monika. Der mittelalterliche Lettner im deutschsprachigen Raum: Typologie und Funktion („Studien zur Internationalen Architektur- und Kunstgeschichte“ 33). Petersberg: Michael Imhof Verlag, 2004.

Soćko, Adam. Układy emporowe w architekturze państwa krzyżackiego. Warszawa: Neriton, 2005.

„Thorner Denkwürdigkeiten von 1345-1547“, ed. by Albert Voigt (Mitteilungen des Coppernicus-Vereins 13), Thorn: Kommissionsverlag von E. Lambeck, 1904.

Trost, Heike. Die Katharinenkirche in Lübeck: franziskanische Baukunst im Backsteingebiet. Von der Bettelordensarchitektur zur Bürgerkirche („Franziskanische Forschungen“, Heft 47). Kevelaer: Butzon\&Bercker, 2006.

Untermann, Matthias, and Leonie Silberer. „Architektur franziskanischer Kirchen und Klosterbauten“. In Franziskus-Licht aus Assisi. Katalog zur Ausstellung im Erzbischöflichen Diözesanmuseum und im Franziskanerkloster Paderborn, ed. by Christoph Stiegemann, Berndt Schmies, and Heinz Dieter Heimann, 140-147. München: Hirmer Verlag, 2011.

Urkundenbuch des Bisthums Culm, ed. by Carl Peter Woelky. Vol. 1. Danzig: Commissionsverlag von Theodor Bertling, 1885.

Wernicke, Julius Emil. Geschichte Thorns aus Urkunden, Dokumenten und Handschriften. Vol. 1. Thorn: Kommissionsverlag von E. Lambeck, 1842.

Woziński, Andrzej. „Artystyczne i ideowe aspekty późnogotyckiego krucyfiksu w pofranciszkańskim kościele”. In Dzieje i skarby kościoła Mariackiego w Toruniu. Materiały z konferencji przygotowanej przez toruński oddział SHS oraz IZiK UMK, Toruń 14-16 kwietnia 2005, ed. by Katarzyna Kluczwajd, 203-221. Toruń: SHS, 2005.

Woziński, Andrzej. „Rzeźba drewniana na Pomorzu Wschodnim w latach 1450-1550”. Doctor’s dissertation, Uniwersytet im. Adama Mickiewicza in Poznań, 1996. 


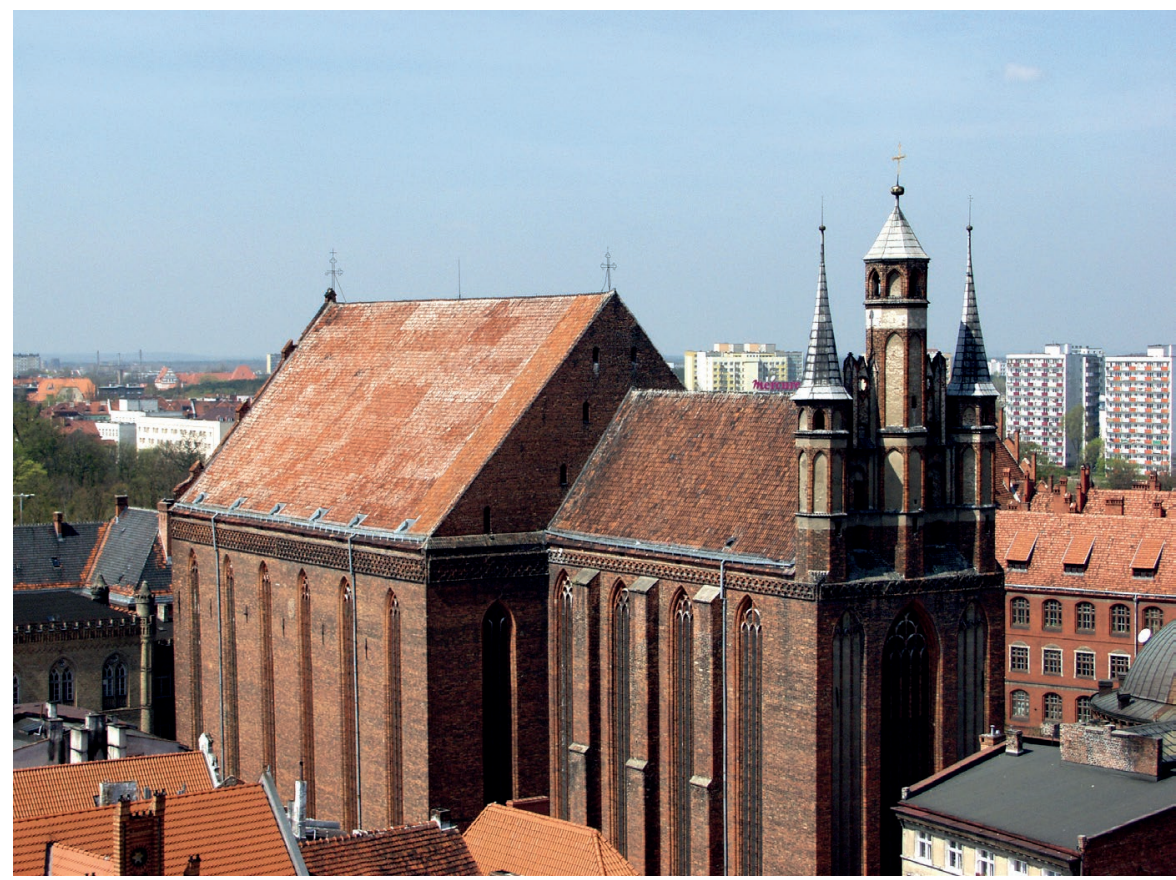

Fig. 1. Toruń, St Mary’s church. Photo by Juliusz Raczkowski

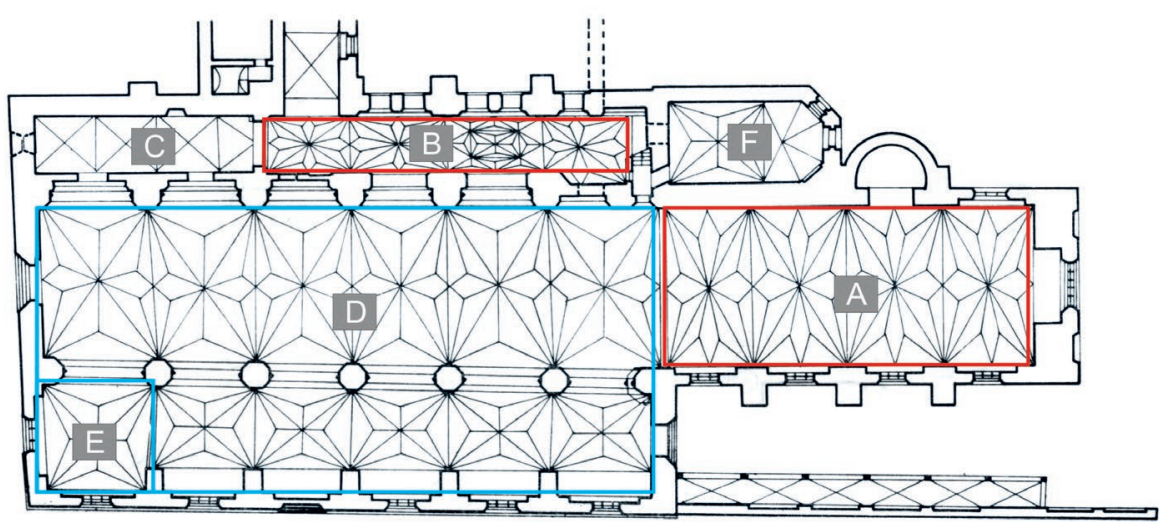

Fig. 2. Toruń, St Mary’s church. Plan. After Teresa Mroczko, Architektura gotycka na ziemi chetmińskiej (Warszawa: PWN, 1980), 297, fig. 134. Elaborated by the authors

A. Ecclesia interior (Friars' choir); B. north aisle - Friars' cloister; C. Holy Grave chapel (?); D. Ecclesia exterior; E. Western chapel; F. Sacristy (private chapel) 


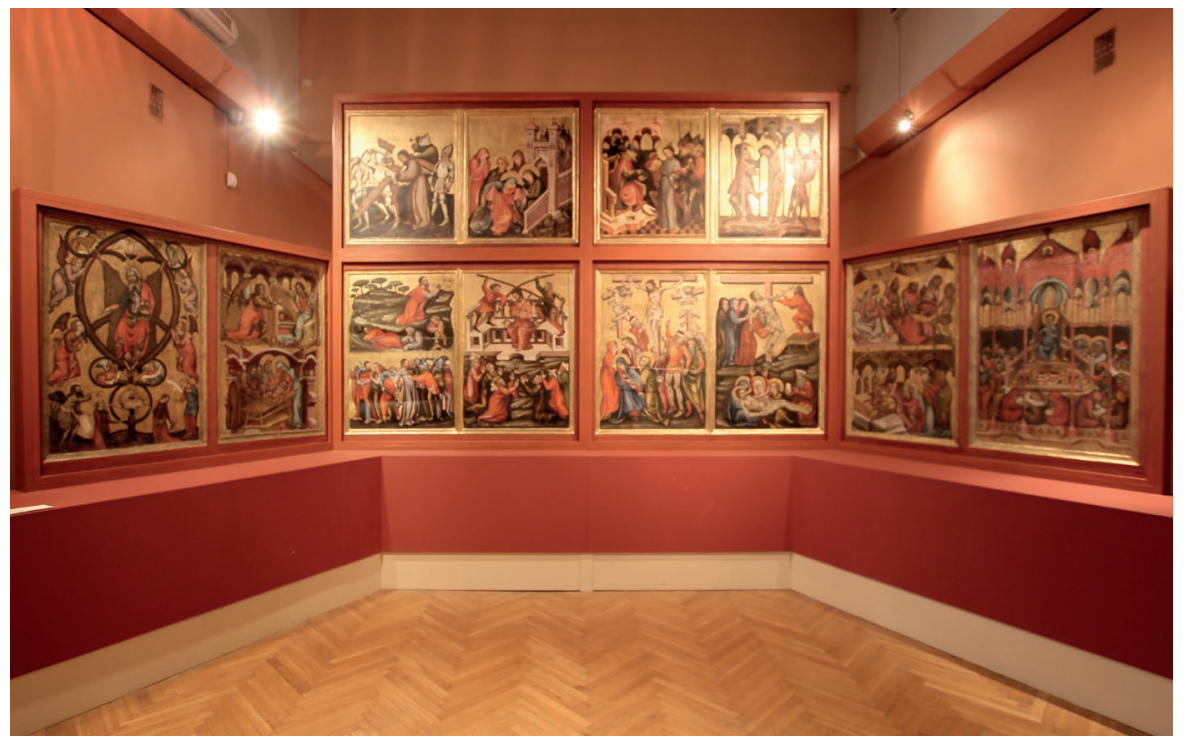

Fig. 3. Pelplin, Diocesan Museum. „Toruń Polyptych” from St Mary’s church in Toruń (Inv. MDP/35/M). Photo by Juliusz Raczkowski 


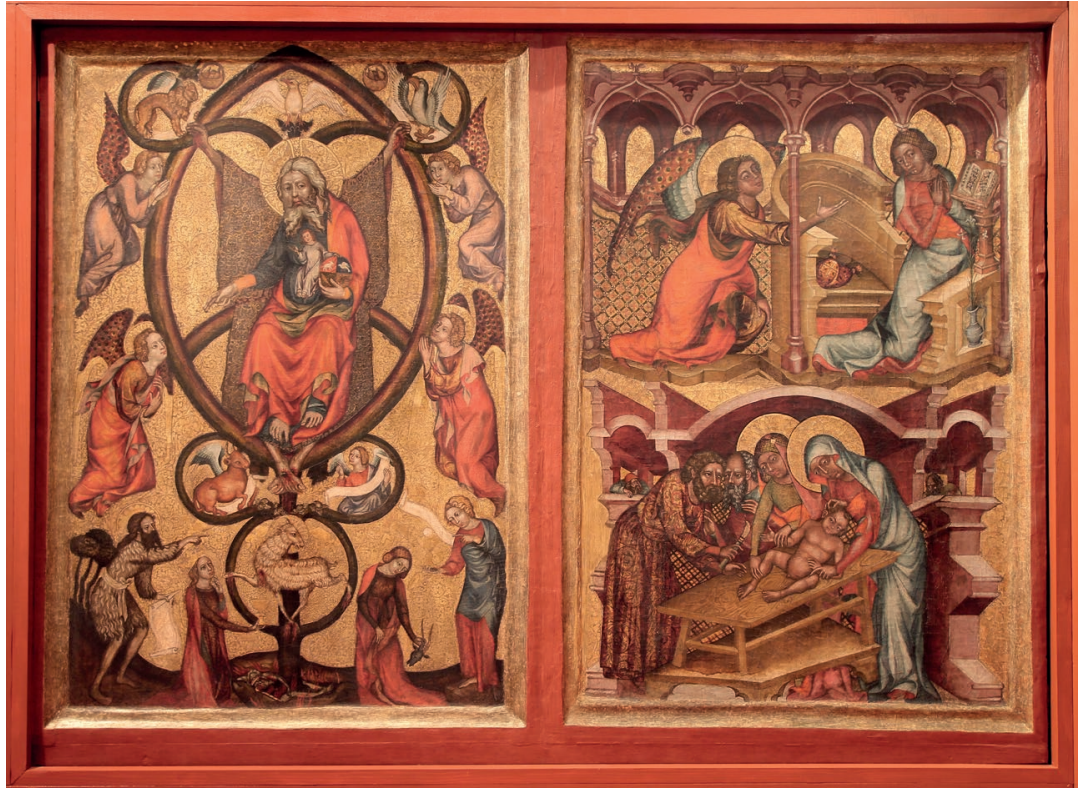

a.

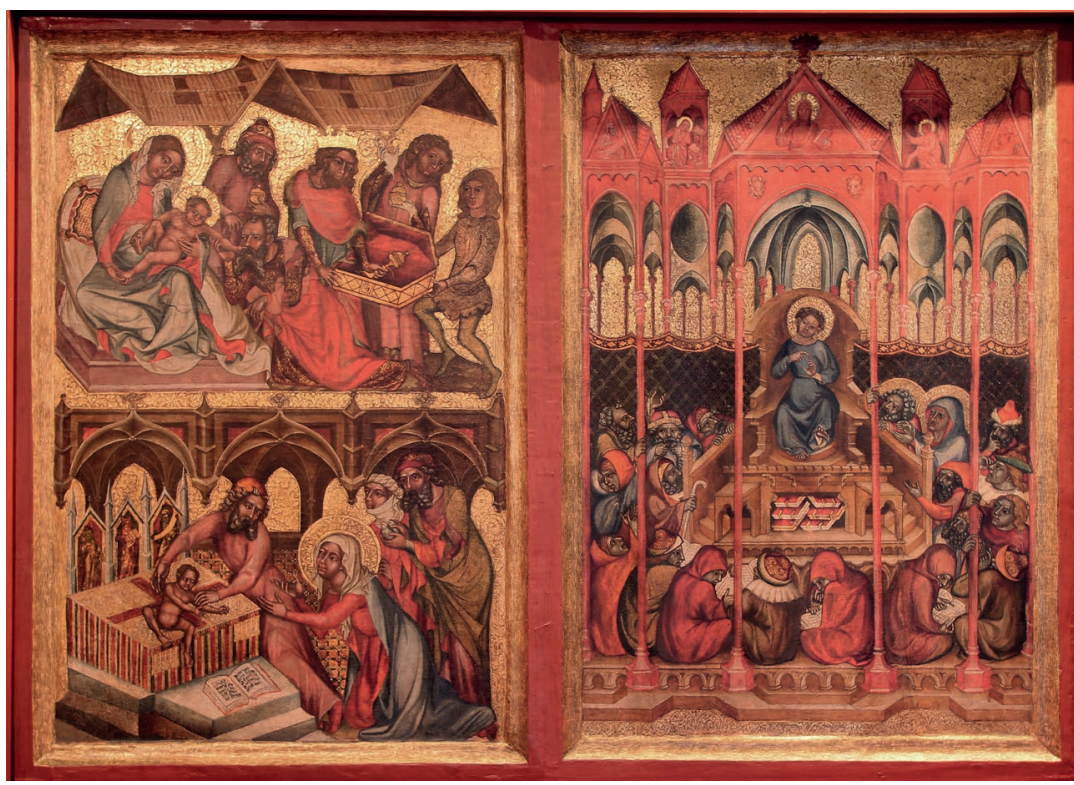

b.

Fig. 4. Pelplin, Diocesan Museum. „Toruń Polyptych” from St Mary’s church in Toruń (Inv. MDP/35/M). Photo by Juliusz Raczkowski

a. left panel: Quinitas, Annunciation, Circumcision of Christ; b. right panel: Adoration of the Magi, Presentation at the Temple, Christ among the Doctors 


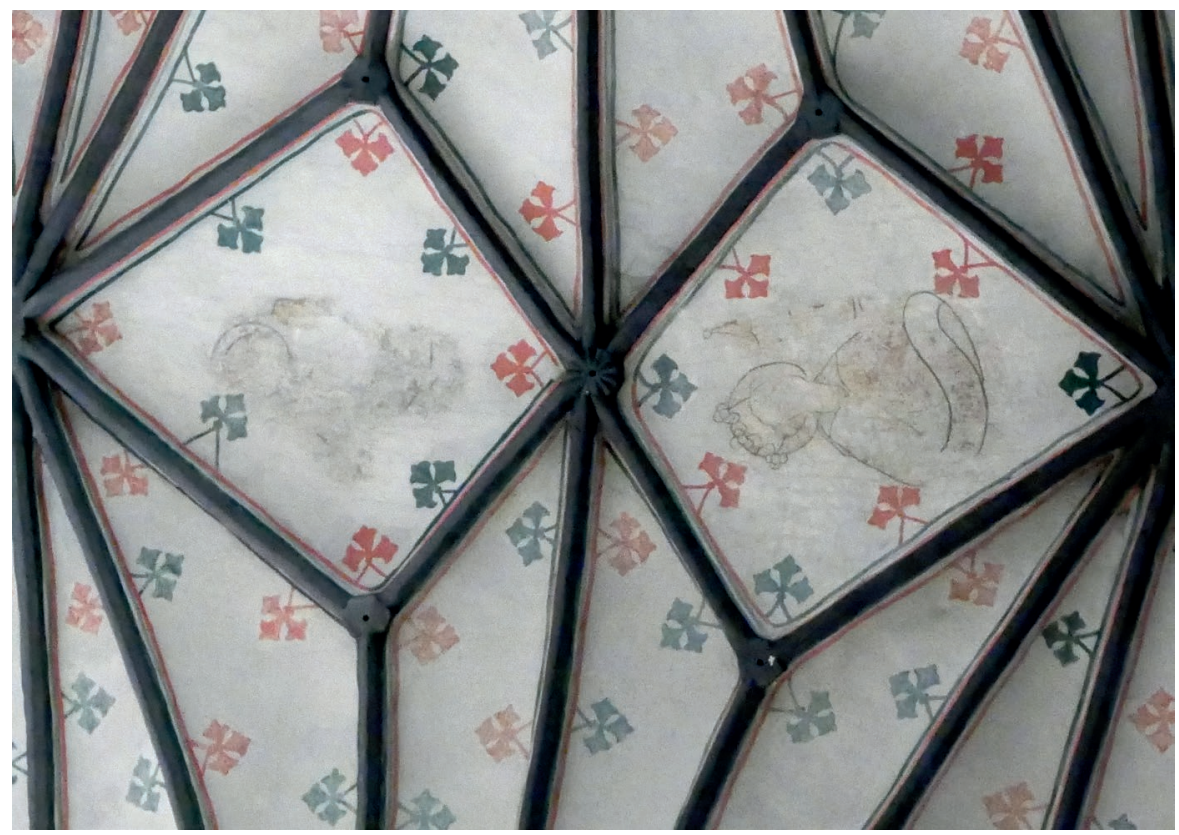

Fig. 5. Toruń, St Mary's church. Wall paintings on the chancel' vaults. Photo by Juliusz Raczkowski 


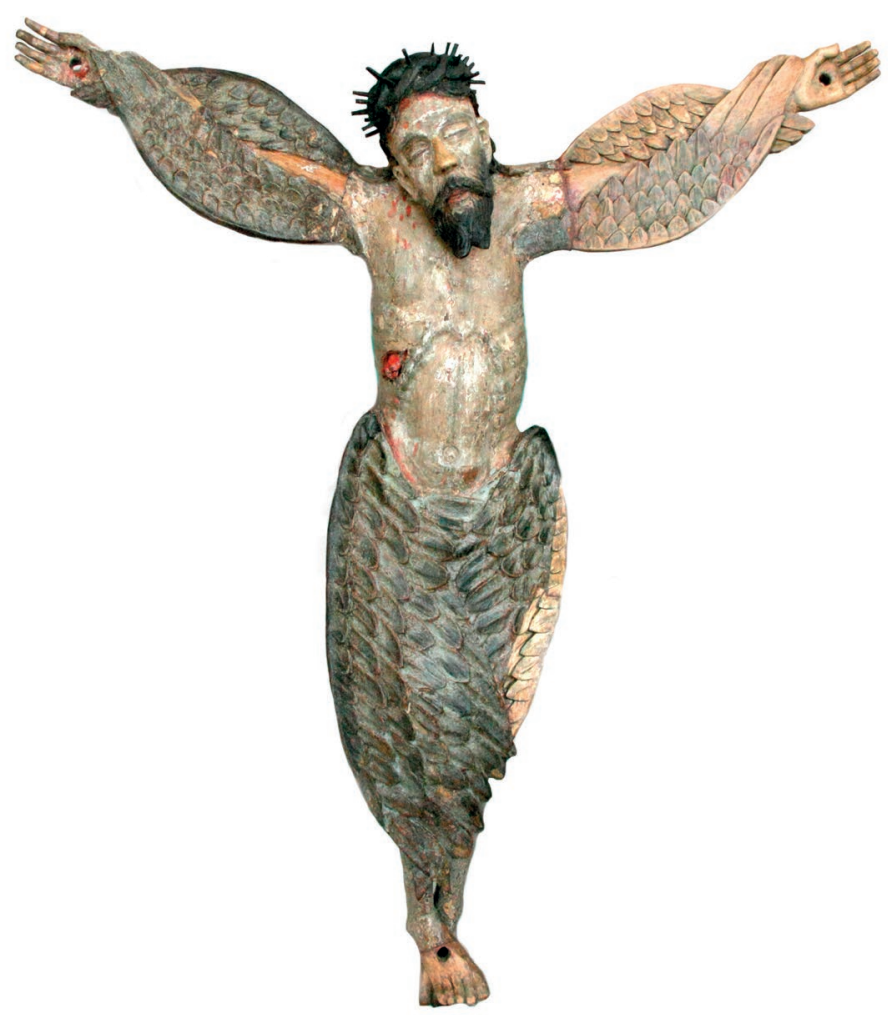

Fig. 6. Skępe, Bernardine cloister. Crucifix (probably from St Mary's church in Toruń). Photo by Juliusz Raczkowski 


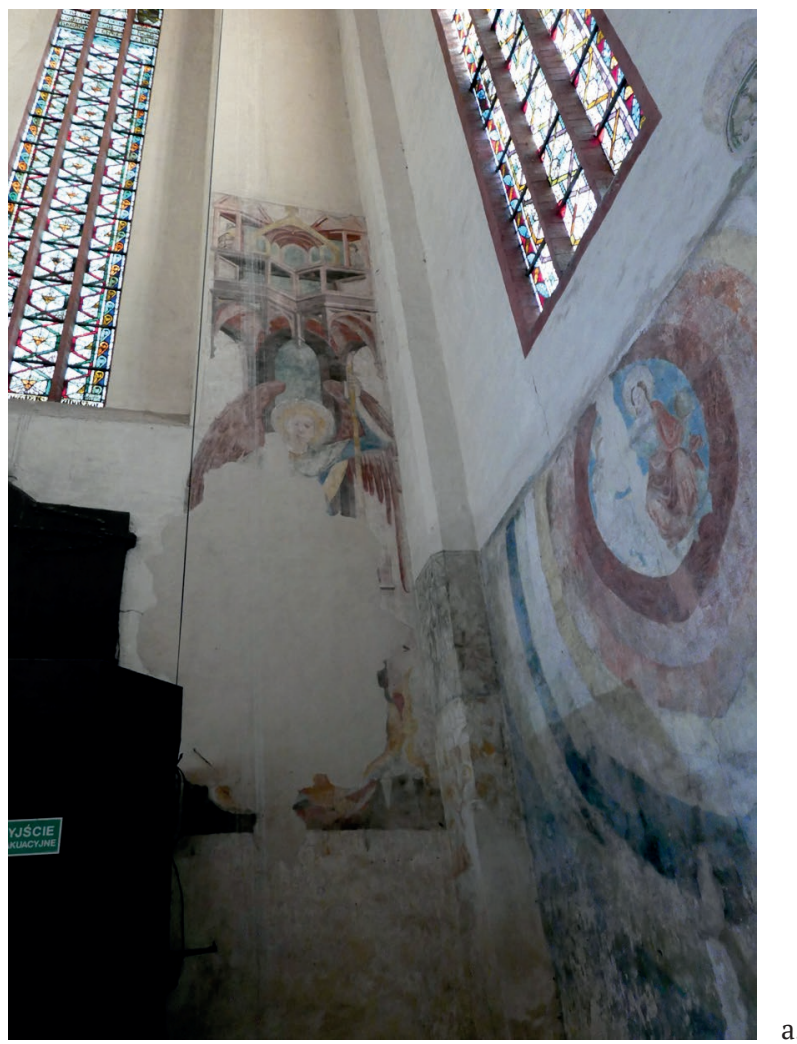

a.

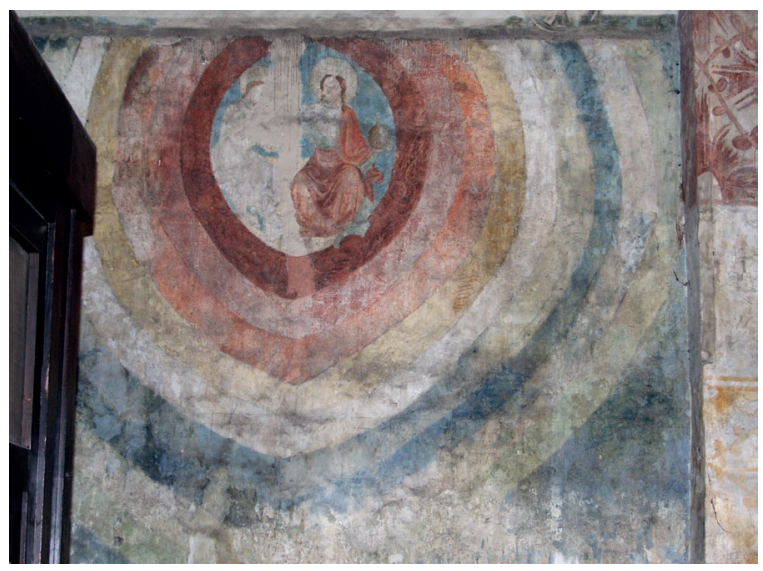

b.

Fig. 7. Torun, St Mary's church. The chapel on the east side of the south aisle. Photo by Juliusz Raczkowski

a. view on the east wall, b. the Coronation of the Virgin on the south wall 


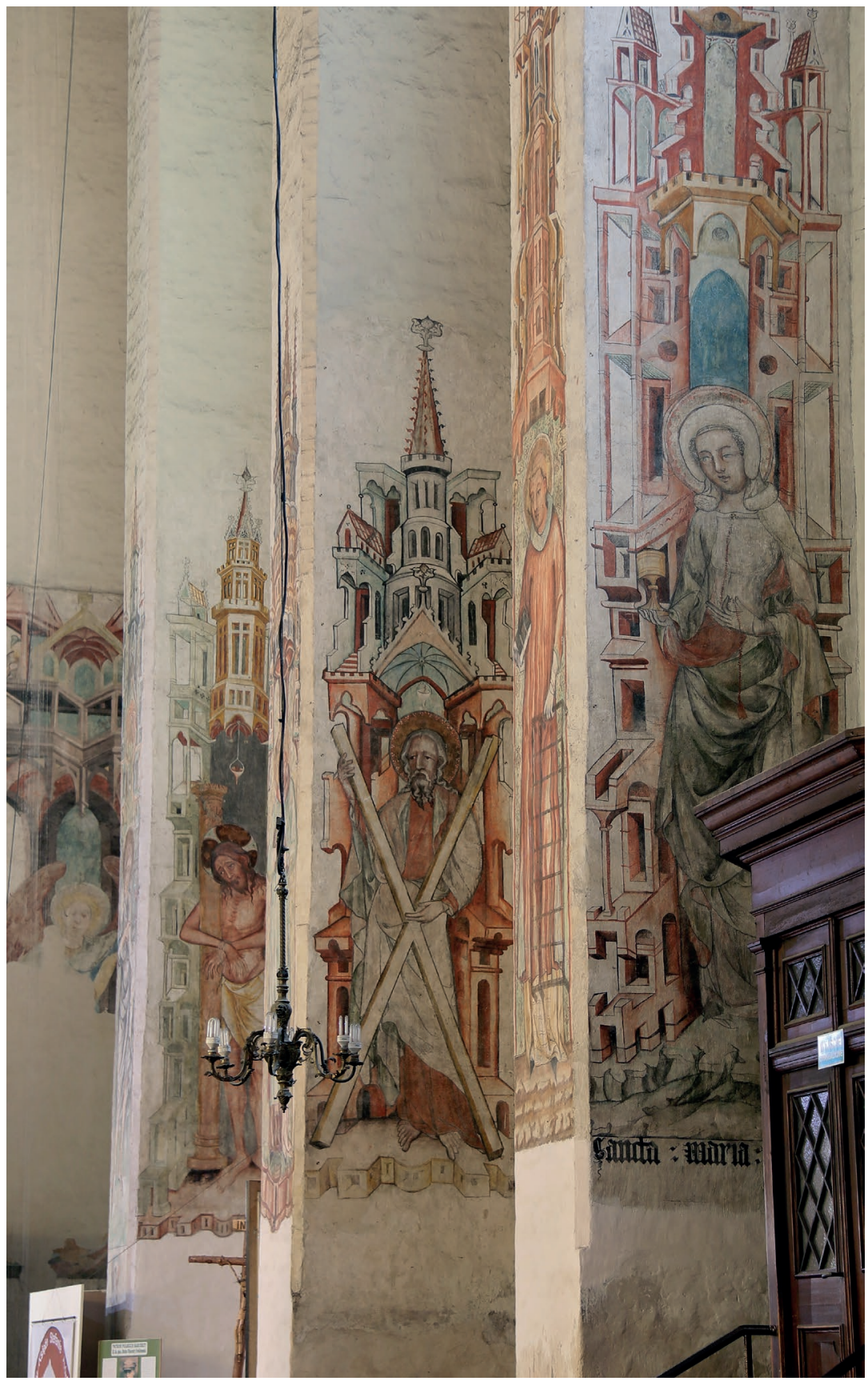

Fig. 8. Torun, St Mary's church. Wall paintings on the buttress in the southern aisle. Photo by Juliusz Raczkowski 
a.
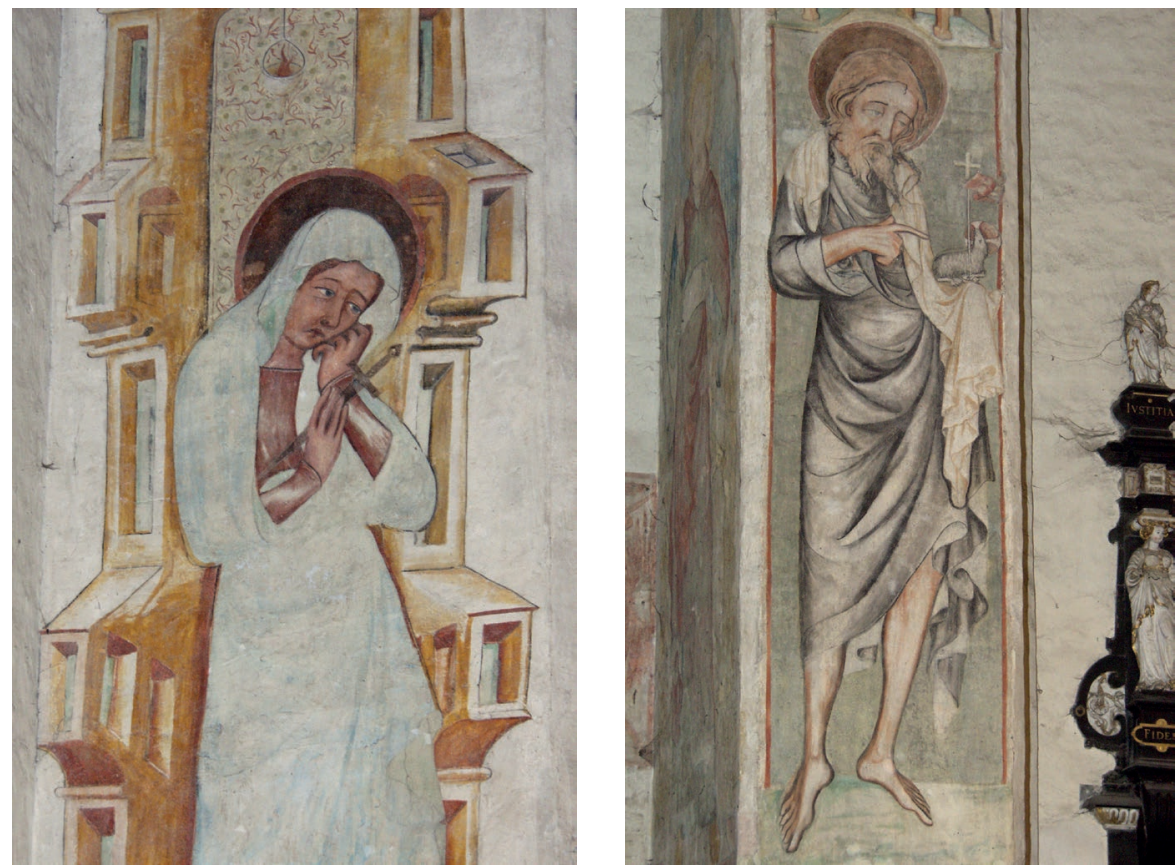

b.

Fig. 9. Torun, St Mary's church. Wall paintings on the buttress in the south aisle. Photo by Juliusz Raczkowski

a. Virgin of Sorrows; b. St John the Baptist 


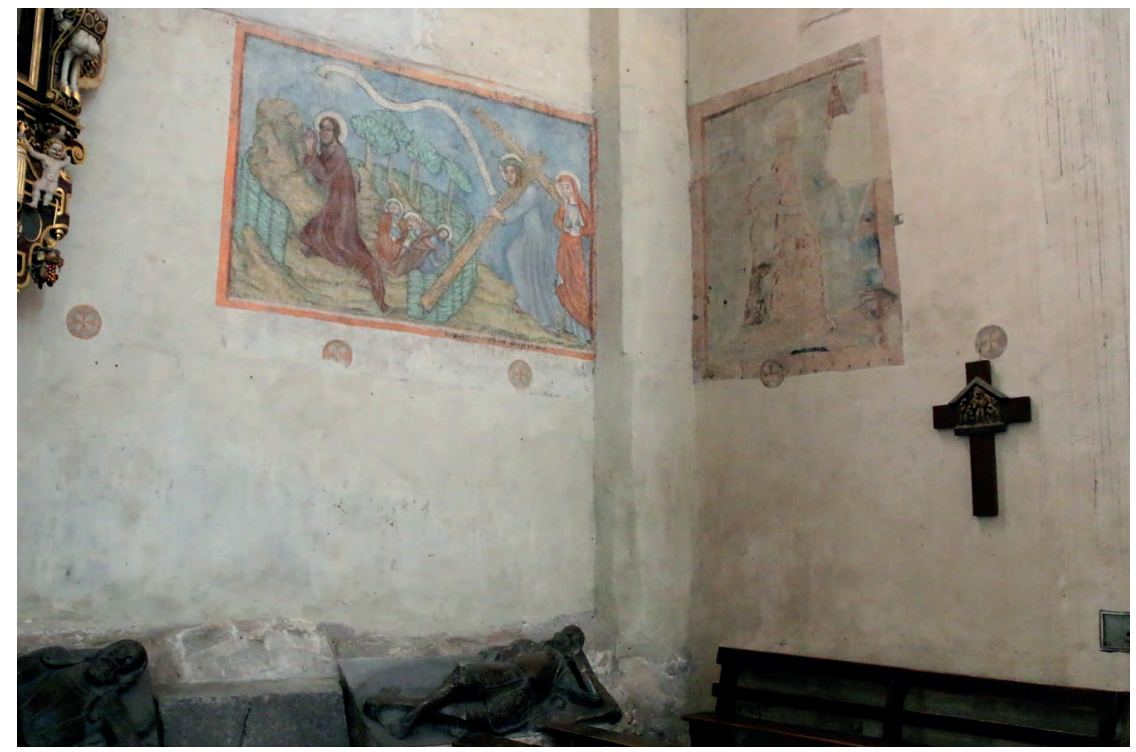

Fig. 10. Toruń, St Mary's church. Chapel in the western span of the south aisle. Photo by Juliusz Raczkowski

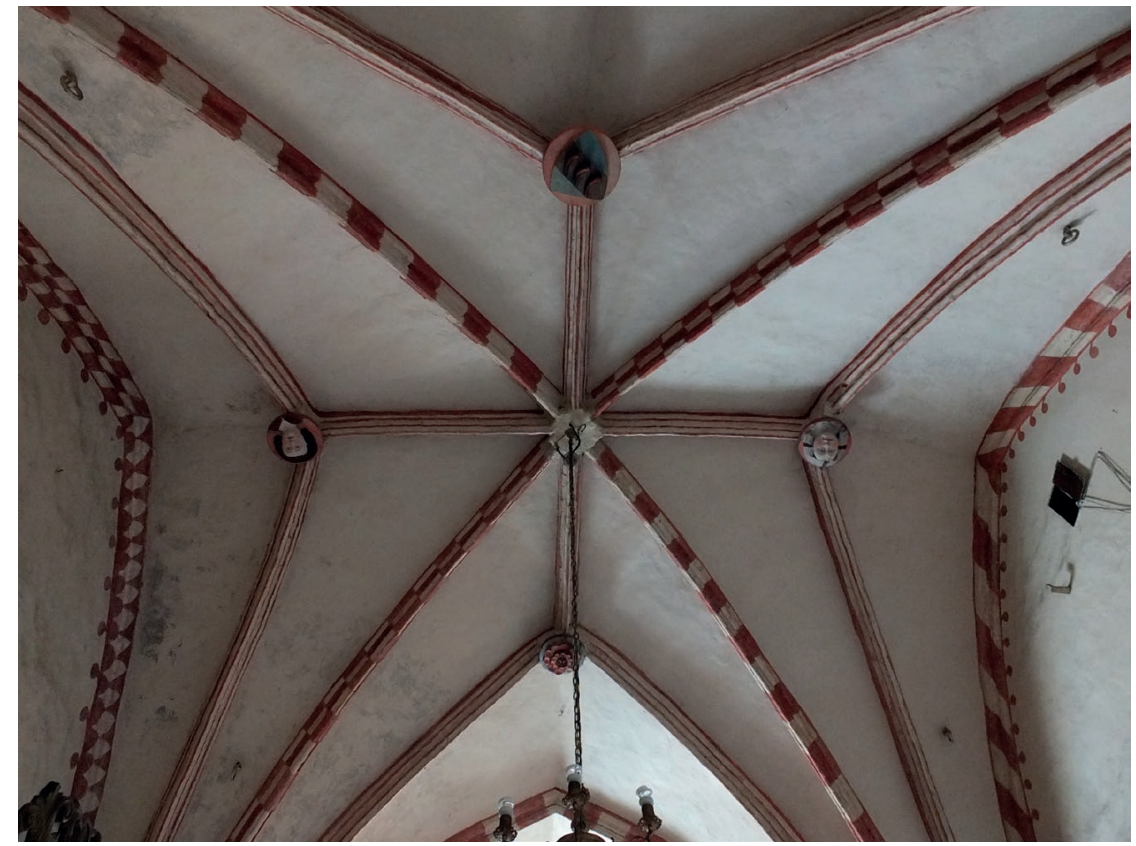

Fig. 11. Toruń, St Mary's church. The vaults of the sacristy. Photo by Juliusz Raczkowski 


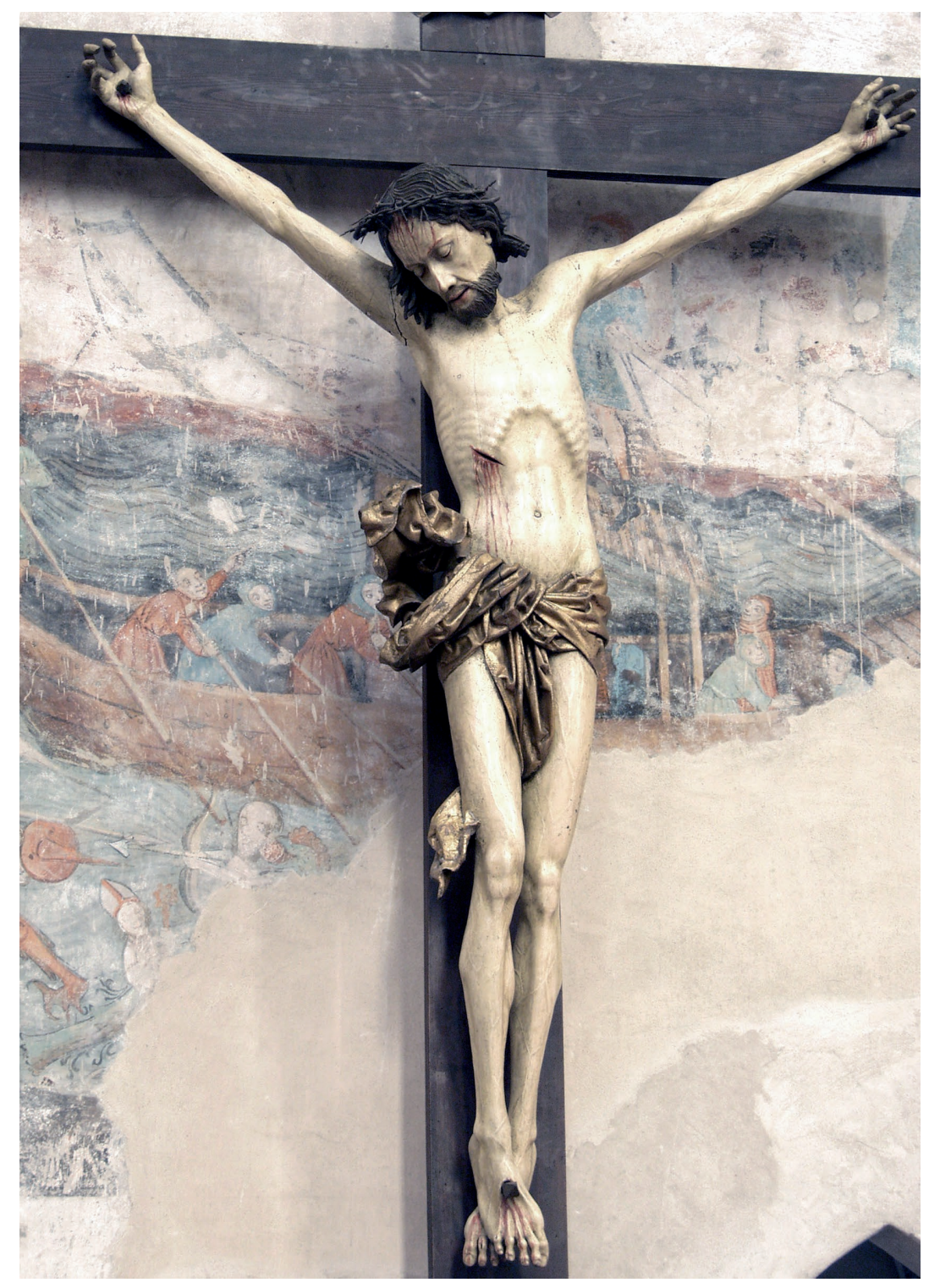

Fig. 12. Toruń, St Mary’s church. Late Gothic crucifix. Photo by Juliusz Raczkowski 